\title{
Ellagic Acid as a Tool to Limit the Diabetes Burden: Updated Evidence
}

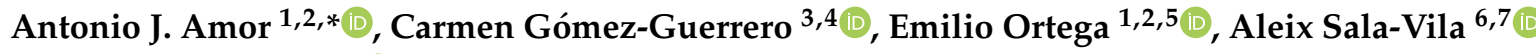 \\ and Iolanda Lázaro $6, *$ (i) \\ 1 Endocrinology and Nutrition Service, Hospital Clínic de Barcelona, 08036 Barcelona, Spain; \\ EORTEGA1@clinic.cat \\ 2 Centro de Investigación Biomédica en Red de la Fisiopatología de la Obesidad y Nutrición (CIBEROBN), \\ Instituto de Salud Carlos III (ISCIII), 28029 Madrid, Spain \\ 3 Renal and Vascular Inflammation Lab, Health Research Institute-Fundación Jiménez Díaz (IIS-FJD), \\ Autonoma University of Madrid (UAM), 28040 Madrid, Spain; cgomez@fjd.es \\ 4 Centro de Investigación Biomédica en Red de Diabetes y Enfermedades Metabólicas \\ Asociadas (CIBERDEM), Instituto de Salud Carlos III (ISCIII), 28029 Madrid, Spain \\ 5 Institut d'Investigacions Biomèdiques August Pi Sunyer (IDIBAPS), 08036 Barcelona, Spain \\ 6 IMIM-Hospital del Mar Medical Research Institute, 08003 Barcelona, Spain; asala3@imim.es \\ 7 Barcelonaßeta Brain Research Center, Pasqual Maragall Foundation, 08005 Barcelona, Spain \\ * Correspondence: ajamor@clinic.cat (A.J.A.); iolan.lazaro@gmail.com (I.L.)
}

Received: 12 November 2020; Accepted: 2 December 2020; Published: 3 December 2020

\begin{abstract}
Oxidative stress contributes not only to the pathogenesis of type 2 diabetes (T2D) but also to diabetic vascular complications. It follows that antioxidants might contribute to limiting the diabetes burden. In this review we focus on ellagic acid (EA), a compound that can be obtained upon intestinal hydrolysis of dietary ellagitannins, a family of polyphenols naturally found in several fruits and seeds. There is increasing research on cardiometabolic effects of ellagitannins, EA, and urolithins (EA metabolites). We updated research conducted on these compounds and (I) glucose metabolism; (II) inflammation, oxidation, and glycation; and (III) diabetic complications. We included studies testing EA in isolation, extracts or preparations enriched in EA, or EA-rich foods (mostly pomegranate juice). Animal research on the topic, entirely conducted in murine models, mostly reported glucose-lowering, antioxidant, anti-inflammatory, and anti-glycation effects, along with prevention of micro- and macrovascular diabetic complications. Clinical research is incipient and mostly involved non-randomized and low-powered studies, which confirmed the antioxidant and anti-inflammatory properties of EA-rich foods, but without conclusive results on glucose control. Overall, EA-related compounds might be potential agents to limit the diabetes burden, but well-designed human randomized controlled trials are needed to fill the existing gap between experimental and clinical research.
\end{abstract}

Keywords: ellagic acid; type 2 diabetes; glucose metabolism; oxidative stress; inflammation; diabetic complications

\section{Introduction}

Type 2 diabetes (T2D) is a growing epidemic, with an estimated prevalence of 463 million people nowadays worldwide and is thought to increase to 700 million by 2045 [1]. Micro- and macrovascular complications are the main cause of morbidity and mortality in diabetic patients [2]. Despite the increasing number of pharmacological options [3], dietary intervention still remains as the cornerstone of the prevention and treatment of T2D [4]. Oxidative stress is a long-known contributor to the T2D 
pathogenesis [5] and diabetic vascular complications [6,7]. Therefore, dietary intake of antioxidants might contribute to limiting the burden of diabetes through multiple ways.

There is compelling evidence of the health benefits of dietary polyphenols, a type of plant-derived antioxidants [8]. Among polyphenols, tannins and ellagitannins, in particular, are believed to protect against diabetic vascular complications [9]. Ellagitannins are found in walnuts [10] and pomegranates, as well as at lower concentrations in several berries [11,12], some beverages, such as brandy and oak-aged red wine [13], and some medicinal plants [14]. Upon hydrolysis, ellagitannins release ellagic acid (EA), which is further metabolized in colon to urolithins [15-17].

In addition to the well-known effect in inhibiting cancer-cell proliferation [10,18-20], further effects have been recently described for EA and its derived metabolites [12]. The link between dietary EA and chronic diseases is attracting increasing interest. In this review are update findings from experimental and clinical studies on EA and the burden of diabetes, delving into three aspects: First, the mechanisms underlying the effect of EA on glucose metabolism; second, how dietary EA might limit diabetic-driven tissue damage via its antioxidant, anti-inflammatory, and anti-glycation properties; and third, whether dietary EA protects against diabetic complications. We include studies involving EA given in isolation, extracts or preparations enriched in EA, and EA-rich foods, mostly pomegranate juice. Walnuts were left out on purpose because of their accumulation of salutary phytochemicals other than EA that act synergistically, blurring the exact contribution of EA to a specific effect. To identify all relevant literature published on the topic, MEDLINE and SCIENCE CITATION INDEX searches were performed, ending February 2020. The keywords used were (ellagitannin* OR ellagic acid* OR urolithin*) AND (diabetes OR glucose OR retinopathy OR nephropathy OR kidney disease OR neuropathy OR cardiovascular OR diabetes complications* OR inflammation* OR glycosylation*). In addition, references cited in published original and review articles were examined until no further study was identified.

\section{Ellagic Acid and Glucose Control}

\subsection{In Vitro Studies}

Some in vitro models focused on the anti-hyperglycemic effects of EA. In HepG2 hepatocytes under high glucose, EA $(15,30 \mu \mathrm{M})$ increased glucose consumption, being the effect of the highest dose akin to the well-known insulin-sensitizer drug metformin $(150 \mu \mathrm{M})$. EA upregulated insulin receptor substrate-1 (IRS1), Akt and extracellular signal-regulated kinase (ERK) phosphorylation under insulin stimulation [21]. Similarly, EA stimulated glucose-induced insulin secretion in mice isolated islets, yet not reaching the effect of the secretagogue drug tolbutamide [22]. Stimulation of insulin secretion was also observed in rat pancreatic islets treated with EA [23]. Many in vitro models reported a dose-dependent effect of EA and its derivatives in inhibiting $\alpha$-glucosidase activity. The studies included EA-rich foods (pomegranate juice [24]), extracts from EA-rich plants, such as pomegranate [25-28] and Mongolian oak cups [29], as well as EA [24,26,27,29] and its gut-derivate urolithin A [24]. A minor inhibitory activity in other carbohydrates hydrolases (such as $\alpha$-amylase) has also been described [26,29]. Dipeptidyl peptidase IV (DPP-IV) has also been studied as a target of EA. Pomegranate juice, EA, and urolithin A displayed a strong effect in murine 3T3-L1 adipocytes, along with inhibition of pancreatic lipase [30]. The in silico DPP-IV inhibition observed after the addition of the extract of arjun tree (Terminalia arjuna) was similar than that observed after the challenge with sitagliptin and vildagliptin, two DPP-IV inhibitors currently used for T2D [30]. Finally, in differentiated murine 3T3-L1 adipocytes, the addition of pomegranate fruit extract or EA significantly suppressed resistin secretion (an adipokine associated with dyslipidemia and insulin resistance) via promoting its degradation at protein level [31]. 


\subsection{Animal Studies}

\subsubsection{Non-Diabetic Murine Models}

In mice under a high-fat diet, 12-week intraperitoneal administration of urolithin A ( $20 \mu \mathrm{g} /$ day $)$ significantly improved systemic insulin sensitivity, attenuated liver steatosis, and reduced adipocyte hypertrophy and macrophage infiltration into the adipose tissue [32]. Fifteen-day dietary pomegranate peel extract $(200 \mathrm{mg} / \mathrm{kg} /$ day $)$ in non-diabetic Wistar albino rats lowered serum glucose levels, while insulin remained unchanged [33]. In female ddY mice subjected to bilateral ovariectomy (a model of insulin resistance), 12-week dietary pomegranate fruit extract (30 mg/kg/day) significantly reduced serum resistin levels without changing serum glucose [31]. Similarly, in high-fat and high-sucrose diet-induced obesity mice (but without diabetes), extracts of pomegranate flower and peel $(250 \mathrm{mg} / \mathrm{kg} /$ day) did not improve fasting glucose levels after 2 or 4 weeks, nor glucose after oral glucose tolerance test (OGTT) or insulin tolerance test after 2 weeks of intervention [34]. The same results were found in high-fat diet-induced obese Balb/c mice, in which 4-week supplementation with pomegranate peel extract $(6 \mathrm{mg} /$ day) neither improved glycemia nor glucose tolerance [35]. A study characterizing an extract of the aerial parts of pea plant (with a high content of polyphenols, including EA) reported that oral treatment with $200 \mathrm{mg} / \mathrm{kg} 30 \mathrm{~min}$ before OGTT displayed an anti-hyperglycemic effect in non-diabetic Swiss-albino mice [36]. Finally, 8-week dietary inclusion of 7\% of raspberry pomace in non-diabetic Wistar albino rats reduced plasma glucose levels, particularly if the raspberry pomace was subjected to fine grinding, a process which increased the polyphenol concentration. The authors related this effect to that observed in the gastrointestinal tract (inhibition of $\alpha$-glucosidase and $\beta$-glucuronidase), along with the plasmatic elevation of the fibroblast growth factor-19 [37].

\subsubsection{Streptozotocin-Induced Diabetic Murine Models}

Streptozotocin (STZ) causes pancreatic beta ( $\beta$ )-cell destruction and, subsequently, compromises insulin production, leading to an insulin-dependent diabetes mellitus. Twelve-week old, neonatal STZ-induced diabetic rats were given a single dose of EA $(25,50$, or $100 \mathrm{mg} / \mathrm{kg}) 60 \mathrm{~min}$ prior to OGTT. EA decreased peak glucose in a dose-dependent manner. The highest dose induced a reduction similar to that of standard drug glibenclamide [22]. Two studies assessed the effects of longer exposures. In the first one, 3-week EA ( $30 \mathrm{mg} / \mathrm{kg} /$ day) improved fasting plasma glucose in a similar way to moderate doses of pioglitazone, a well-established anti-hyperglycemic agent. The combination of EA $(10 \mathrm{mg} / \mathrm{kg} /$ day $)$ and pioglitazone $(10 \mathrm{mg} / \mathrm{kg} /$ day $)$ acted synergistically [38]. In the second study, 8-week EA $(50 \mathrm{mg} / \mathrm{kg} /$ day) decreased fasting plasma glucose to a similar extent than subcutaneous Neutral Protamine Hagedorn (NPH) insulin (6 UI/day) [39].

STZ-induced diabetic murine models have repeatedly been used to test pomegranate extracts. Oral administration of a single dose of pomegranate seed extract $(600 \mathrm{mg} / \mathrm{kg})$ lowered by $52 \%$ the blood glucose at $12 \mathrm{~h}$, inducing a higher effect than a dose of $200 \mathrm{mg} / \mathrm{kg}$ of chlorpropamide [40]. Longer exposures have also been tested. Pomegranate peel extract (5, 15, 25, and $100 \mathrm{mg} / \mathrm{kg}$ administered every 2 days for 10 days) significantly reduced fasting blood glucose in a dose-dependent manner, while increasing insulin levels [41]. Similar results were observed after 4-week treatment with extracts of pomegranate leaf or fruit peel (100 and $200 \mathrm{mg} / \mathrm{kg} /$ day), although not reaching that observed with glibenclamide [42]. Pomegranate flowers aqueous extract $(250$ and $500 \mathrm{mg} / \mathrm{kg}$ for 3 weeks) also reduced fasting blood glucose and improved lipid parameters in STZ-induced diabetic rats [43]. Finally, 4-week oral administration of pomegranate peel extract alone $(400 \mathrm{mg} / \mathrm{kg} /$ day $)$ or in combination with black bean peel extract ( $200 \mathrm{mg} / \mathrm{kg} /$ day each) ameliorated hyperglycemia and limited the loss of pancreatic mass secondary to STZ administration [44].

Other extracts from EA-rich medicinal plants or vegetables have also been studied. In a high-fat diet and STZ-induced diabetic rats, 8-week administration of an extract of Chinese olive (Canarium album L., 50 and $150 \mathrm{mg} / \mathrm{kg} /$ day) limited body weight gain and hepatic steatosis, and reduced glucose in parallel with improving of insulin signaling pathway (decrease in phosphorylated IRS1 and up-regulation of 
phosphorylated Akt protein expression) [45]. Other studies tested extracts from amla (Emblica officinalis, 250 and $500 \mathrm{mg} / \mathrm{kg} /$ day) [22] or arjun tree (Terminalia arjuna, $500 \mathrm{mg} / \mathrm{kg} /$ day) [30] in STZ-induced diabetic rats. The first study, which involved a 4-week intervention, reported on decrease in plasma glucose in a dose-dependent manner. This was believed to be mediated by changes in pancreatic $\beta$-cell functionality [22]. In the second one, a 5-week supplementation with the extract significantly restored both glucose and hemoglobin $\mathrm{A} 1 \mathrm{c}(\mathrm{HbA} 1 \mathrm{c})$ levels to a similar extent than the antidiabetic drug vildagliptin [30].

Finally, two studies assessed the effect of pomegranate juice $(1 \mathrm{~mL} /$ day for 3 weeks) on glucose parameters in STZ- and nicotinamide-induced diabetic Sprague-Dawley rats [46,47]. Glucose remained unchanged [46] or significantly decreased [47] compared to rats fed control diet. However, both studies reported benefits in the $\beta$-cell function, by increasing plasma insulin levels [47] and increasing average size and number of islets of Langerhans in the pancreas [46]. Finally, pomegranate juice (100 and $300 \mathrm{mg} / \mathrm{kg} /$ day) was used in a similar diabetic model but with a longer exposure (6 weeks). Animals fed with pomegranate juice, particularly those at the highest dose, showed a significant decrease in plasma glucose, along with an increase in the insulin levels and a decrease in Homeostatic Model Assessment for Insulin Resistance (HOMA-IR) [48].

\subsubsection{Alloxan-Induced Diabetic Murine Models}

Alloxan-induced diabetes is another form of insulin-dependent diabetes mellitus, because of a partial degradation $\beta$-cells in pancreatic islets. In this experimental model, pomegranate peel extracts were orally administered in three independent studies at doses ranging from 75 to $200 \mathrm{mg} / \mathrm{kg} / \mathrm{day}$ for 15 days [49], 6 weeks [50], and 8 weeks [51]. All studies consistently reported on a decrease in glucose levels in parallel with an increase in insulin secretion [49-51]. One-week administration of an ethanolic extract of pomegranate leaves $(500 \mathrm{mg} / \mathrm{kg} /$ day) decreased blood glucose and increased tissue glycogen content (liver, skeletal and cardiac muscles) [52]. A study explored the glycemic effects after acute and 3-week administration of an aqueous extract of pomegranate arils at different doses $(100,200$, and $350 \mathrm{mg} / \mathrm{kg} /$ day). The authors found that both treatments lowered glycemia, as assessed either by fasting blood glucose or OGTT, and increased insulin levels through a modulation of the phosphoinositide 3-kinase (PI3K)/Akt pathway [53]. Finally, a similar effect in glucose metabolism was observed after the administration of pomegranate rind extract (or its spray dried biopolymeric dispersions) [54].

Extracts from EA-rich plants have also been studied. A single dose (250 or $500 \mathrm{mg} / \mathrm{kg}$ ) of an ethanolic extract from leaves of maire (Crataegus azarolus var. eu-azarolus, a spiny tree rich in phenolic components, EA being one of the most abundant) significantly decreased plasma glucose after OGTT [55]. A repeated administration (30 days) also induced an hypolipidemic effect [55]. Fifteenday supplementation with an ethanolic extract from Mongolian oak cups ( $800 \mathrm{mg} / \mathrm{kg} / \mathrm{day})$ improved glucose levels and lipid parameters [56].

Finally, a study supplemented alloxan-induced diabetic Sprague-Dawley rats with either walnut leaf, coriander leaf or pomegranate seed $(60 \mathrm{~g} / \mathrm{kg} /$ day, each) for 15 days. Only supplementation with walnut leaf significantly reduced blood glucose, while increasing density of islets in pancreatic tissue, percentage of $\beta$-cells, and islet size [57].

\subsubsection{Other Diabetic Murine Models}

In an experimental model of insulin resistance/T2D (albino rats fed with a high-fat and high-fructose diet for 2 months), 2-week EA supplementation ( $10 \mathrm{mg} / \mathrm{kg} /$ day) improved glucose/insulin balance in serum, while enhancing insulin signaling, autophosphorylation, adiponectin receptors, glucose transporters, and apoptotic markers in glucose-sensitive tissues (i.e., liver, pancreas, adipose tissue, and brain) [58]. In contrast, in KK-Ay mice fed high-fat diet (a model for T2D possessing insulin resistance), dietary supplementation with EA $(0.1 \%)$ for 68 days did not affect serum glucose or insulin, although it reduced serum resistin and improved serum lipid profile and hepatic steatosis [59]. 
Four-week dietary supplementation with EA ( $50 \mathrm{mg} / \mathrm{kg} /$ day) reduced fasting blood glucose, insulin resistance, and liver steatosis in adult female Goto Kakizaki rats (a non-obese spontaneous model of T2D) [60].

Finally, 2-week inclusion of the methanolic extract of pomegranate flower (500 mg/kg/day) lowered plasma glucose levels in non-fasted Zucker diabetic fatty rats (a genetic model of obesity and T2D), whereas it had little effect in fasted animals. In addition, the extract inhibited the increase of plasma glucose levels after a challenge with sucrose load [25].

\subsection{Human Studies}

Most of the human studies have used pomegranate juice as a source of EA (Table 1). Three studies evaluated the effects of the acute administration of this juice on glycemic parameters [61-63]. In the only study including participants with T2D, blood samples were collected after a 12-h fast, then 1 and $3 \mathrm{~h}$ after administration of $1.5 \mathrm{~mL}$ of pomegranate juice per kg body weight. A significant decrease in plasma glucose was found at $3 \mathrm{~h}$, especially in those at lower initial fasting plasma glucose levels. An improvement both in insulin resistance (HOMA-IR) and in $\beta$-cell function (HOMA \%B) underlined this hypoglycemic effect [61]. Similarly, in healthy adults, concomitant consumption of bread and pomegranate juice (but not a pomegranate-based supplement) significantly attenuated the area under the curve for bread-derived glucose and peak blood glucose [62]. In contrast, no effects were found in a study including pediatric patients with some features of metabolic syndrome but without T2D [63]. Longer exposures have been tested in heterogeneous populations (Table 1). Two non-randomized studies conducted in T2D participants found mixed results for fasting plasma glucose $[64,65]$. The bulk of randomized clinical trials on the topic $[63,66-76]$ reported on neutral results, except for a study conducted in healthy patients, in which 4-week consumption of pomegranate juice lowered fasting plasma insulin and HOMA-IR compared to a control with equivalent amount of carbohydrates [69]. 
Table 1. Human studies assessing the glucose-lowering effects of ellagic acid (EA).

\begin{tabular}{|c|c|c|c|c|c|c|c|c|c|c|}
\hline Reference & $\begin{array}{l}\text { Sample } \\
\text { Size }\end{array}$ & $\begin{array}{l}\text { Study } \\
\text { Design }\end{array}$ & $\begin{array}{c}\text { Participants' } \\
\text { Characteristics }\end{array}$ & $\begin{array}{l}\text { T2D } \\
(\%)\end{array}$ & $\begin{array}{l}\text { Age } \\
\text { (Years) }\end{array}$ & $\begin{array}{l}\text { Sex } \\
(\mathrm{M} / \mathrm{F})\end{array}$ & $\begin{array}{c}\text { BMI } \\
\left(\mathrm{kg} / \mathrm{m}^{2}\right)\end{array}$ & Interventions & Duration & Main Results \\
\hline \multicolumn{11}{|c|}{ Pomegranate juice } \\
\hline \multirow[b]{2}{*}{ [61] } & \multirow[b]{2}{*}{85} & \multirow[b]{2}{*}{ NR, SA } & \multirow[b]{2}{*}{ T2D (85) } & \multirow[b]{2}{*}{100} & \multirow[b]{2}{*}{ NA } & \multirow[b]{2}{*}{$40 / 45$} & \multirow[b]{2}{*}{ NA } & \multirow[b]{2}{*}{$1.5 \mathrm{~mL} / \mathrm{kg}$ bw } & \multirow[b]{2}{*}{1 single dose } & - $\downarrow$ FPG and HOMA-IR \\
\hline & & & & & & & & & & $\begin{array}{l}\text { - } \uparrow \mathrm{HOMA} \% \mathrm{~B} \text { after } 3 \mathrm{~h} \text { of } \\
\text { administration }\end{array}$ \\
\hline [62] & 16 & $\mathrm{R}, \mathrm{SB}, \mathrm{C}$ & Healthy & 0 & $31 \pm 5$ & NA & $23 \pm 3$ & $\begin{array}{c}\text { PJ } 200 \mathrm{~mL} \text { vs. Placebo } \\
\text { (sugar-balanced water), } \\
\text { before bread consumption }\end{array}$ & 1 single dose & $\begin{array}{l}\text { - } \downarrow \text { incremental AUC and } \\
\text { peak glucose after PJ }\end{array}$ \\
\hline \multirow[t]{2}{*}{ [63] } & \multirow[t]{2}{*}{30} & \multirow[t]{2}{*}{$\mathrm{R}, \mathrm{P}$} & \multirow[t]{2}{*}{ MetS, adolescents } & \multirow[t]{2}{*}{0} & \multirow{2}{*}{$13.4 \pm 1.1$} & \multirow[t]{2}{*}{$16 / 14$} & \multirow{2}{*}{$27.1 \pm 1.1$} & \multirow{2}{*}{$\begin{array}{c}\text { PJ (240 mL/d) vs. grape juice } \\
18 \mathrm{~mL} / \mathrm{kg} / \mathrm{d}\end{array}$} & 1 single dose & $\begin{array}{l}\bullet \approx \text { FPG (both arms) after } \\
4 \mathrm{~h} \text { of consumption }\end{array}$ \\
\hline & & & & & & & & & $4 \mathrm{wks}$ & - $\approx$ FPG in both arms \\
\hline [64] & 50 & NR, SA & $\mathrm{T} 2 \mathrm{D}$ & 100 & $45 \pm 8$ & NA & $30 \pm 3$ & PJ $200 \mathrm{~mL} / \mathrm{d}$ & $6 \mathrm{wks}$ & $\bullet \downarrow$ FPG \\
\hline [65] & 31 & NR, SA & $\mathrm{T} 2 \mathrm{D}$ & 100 & $46.0 \pm 8.3$ & $15 / 16$ & $29.5 \pm 0.7$ & concentrated PJ $50 \mathrm{~g} / \mathrm{d}$ & 4 wks & $\bullet \approx \mathrm{FPG}$ \\
\hline [66] & 45 & $\mathrm{R}, \mathrm{DB}, \mathrm{P}$ & stable CHD & 24 & $69.0 \pm 10.0$ & $40 / 5$ & $28.5 \pm 5.6$ & $\begin{array}{l}\text { PJ } 240 \mathrm{~mL} / \mathrm{d} \text { vs. Placebo } \\
\text { (modified sports beverage) }\end{array}$ & 12 wks & - $\approx \mathrm{FPG}$ and $\mathrm{HbA} 1 \mathrm{c}$ \\
\hline [67] & 60 & $\mathrm{R}, \mathrm{SB}$ & $\mathrm{T} 2 \mathrm{D}$ & 100 & $54.7 \pm 8.4$ & $30 / 30$ & $27.3 \pm 3.7$ & $\begin{array}{c}\text { PJ } 200 \mathrm{~mL} / \mathrm{d} \text { vs. Control } \\
\text { (untreated) }\end{array}$ & $6 \mathrm{wks}$ & $\bullet \approx \mathrm{FPG}$ \\
\hline \multirow{3}{*}{ [68] } & \multirow{3}{*}{30} & \multirow{3}{*}{$\mathrm{R}, \mathrm{DB}, \mathrm{C}$} & \multirow{3}{*}{ MetS } & \multirow{3}{*}{0} & \multirow{3}{*}{$51.6 \pm 10.0$} & \multirow{3}{*}{$13 / 17$} & \multirow{3}{*}{ NA } & \multirow{3}{*}{$\begin{array}{l}\text { PJ } 500 \mathrm{~mL} / \mathrm{d} \text { vs. Placebo } \\
\text { (equivalent in sugar and acid } \\
\text { content, without } \\
\text { polyphenols) }\end{array}$} & \multirow{3}{*}{$1 \mathrm{wk}$} & $\bullet \approx \mathrm{FPG}$ \\
\hline & & & & & & & & & & $\bullet \approx$ insulin \\
\hline & & & & & & & & & & $\bullet \approx H O M A-I R$ \\
\hline [69] & 30 & $\mathrm{R}, \mathrm{DB}, \mathrm{P}$ & stable COPD & 0 & $61.7 \pm 10.0$ & NA & $31.0 \pm 5.3$ & $\begin{array}{l}\text { PJ } 400 \mathrm{~mL} / \mathrm{d} \text { vs. Placebo } \\
\text { (synthetic flavored drink) }\end{array}$ & $5 \mathrm{wks}$ & $\bullet \approx \mathrm{FPG}$ \\
\hline \multirow{4}{*}{ [70] } & \multirow{4}{*}{20} & \multirow{4}{*}{$\mathrm{R}, \mathrm{DB}, \mathrm{P}$} & & & & & & & & $\bullet \approx$ FPG, AUC glucose \\
\hline & & & & & & & & & & - insulin, AUC insulin \\
\hline & & & Obesity & 0 & $37.3 \pm 9.4$ & NA & $34.5 \pm 3.6$ & PJ 120 mL/d vs. Placebo & $4 \mathrm{wks}$ & $\begin{array}{l}\text { - insulinogenic index, } \\
\text { Matsuda index }\end{array}$ \\
\hline & & & & & & & & & & - $\downarrow$ insulin and HOMA-IR \\
\hline & & & & & & & & PI 250 mL/d vs. Placebo & & $\bullet \approx \mathrm{FPG}$ \\
\hline [72] & 44 & $\mathrm{R}, \mathrm{DB}, \mathrm{P}$ & T2D & 100 & $55.9 \pm 6.7$ & $23 / 21$ & $29.0 \pm 4.0$ & (equivalent in sugar content) & $12 \mathrm{wks}$ & • $\approx$ insulin or HOMA-IR \\
\hline
\end{tabular}


Table 1. Cont.

\begin{tabular}{|c|c|c|c|c|c|c|c|c|c|c|}
\hline Reference & $\begin{array}{l}\text { Sample } \\
\text { Size }\end{array}$ & $\begin{array}{l}\text { Study } \\
\text { Design }\end{array}$ & $\begin{array}{c}\text { Participants' } \\
\text { Characteristics }\end{array}$ & $\begin{array}{l}\text { T2D } \\
(\%)\end{array}$ & $\begin{array}{l}\text { Age } \\
\text { (Years) }\end{array}$ & $\begin{array}{c}\text { Sex } \\
(\mathrm{M} / \mathrm{F})\end{array}$ & $\begin{array}{c}\text { BMI } \\
\left(\mathrm{kg} / \mathrm{m}^{2}\right)\end{array}$ & Interventions & Duration & Main Results \\
\hline [73] & 21 & $\mathrm{R}, \mathrm{SB}, \mathrm{P}$ & Hypertension & 0 & $52.9 \pm 8.7$ & $6 / 15$ & $27.4 \pm 3.8$ & $\begin{array}{l}\text { PJ } 150 \text { mL/d vs. Placebo } \\
\text { (water) }\end{array}$ & $2 \mathrm{wks}$ & $\bullet \approx \mathrm{FPG}$ \\
\hline \multirow[b]{2}{*}{ [74] } & \multirow[b]{2}{*}{77} & \multirow[b]{2}{*}{ R, DB, P } & \multirow[b]{2}{*}{$\begin{array}{l}\text { Overweight, } \\
\text { women }\end{array}$} & \multirow[b]{2}{*}{0} & \multirow[b]{2}{*}{$41.5 \pm 12.5$} & \multirow[b]{2}{*}{$0 / 77$} & \multirow[b]{2}{*}{$28.4 \pm 2.2$} & \multirow{2}{*}{$\begin{array}{l}\text { PV-based beverage } 200 \mathrm{~mL} / \mathrm{d} \\
\text { vs. Placebo (equivalent in } \\
\text { sugar and acid content) }\end{array}$} & \multirow[b]{2}{*}{$8 \mathrm{wks}$} & $\bullet \approx \mathrm{FPG}$ \\
\hline & & & & & & & & & & $\bullet \approx$ FPI, HOMA-IR \\
\hline [75] & 20 & $\mathrm{R}, \mathrm{DB}, \mathrm{P}$ & $\begin{array}{c}\text { Endurance-based } \\
\text { athletes }\end{array}$ & 0 & $35.3 \pm 9.9$ & $20 / 0$ & NA & $\begin{array}{l}\text { PJ } 200 \text { mL/d vs. PJ diluted 1:1 } \\
\text { with water ( } 200 \mathrm{~mL} / \mathrm{d}) \text { vs. } \\
\text { seasonal fruit (equivalent } \\
\text { energy) }\end{array}$ & 3 wks & $\bullet \approx \mathrm{FPG}$ \\
\hline [76] & 10 & $\mathrm{R}, \mathrm{SB}$ & Healthy & 0 & $31.8 \pm 6.6$ & $5 / 5$ & NA & PJ 500 mL/d vs. Placebo & 2 wks & $\bullet \approx \mathrm{FPG}$ \\
\hline \multicolumn{11}{|c|}{ Pomegranate extracts } \\
\hline \multirow[b]{2}{*}{ [62] } & \multirow[b]{2}{*}{16} & \multirow[b]{2}{*}{$\mathrm{R}, \mathrm{DB}, \mathrm{C}$} & \multirow[b]{2}{*}{ Healthy } & \multirow[b]{2}{*}{0} & \multirow[b]{2}{*}{$26 \pm 6$} & \multirow[b]{2}{*}{ NA } & \multirow[b]{2}{*}{$23 \pm 2$} & \multirow{2}{*}{$\begin{array}{c}400 \text { mg PE vs. } 200 \mathrm{mg} \\
\text { placebo+200 mg PE vs. } 400 \\
\text { mg placebo (before bread } \\
\text { consumption) }\end{array}$} & \multirow[b]{2}{*}{1 single dose } & - $\approx$ Incremental AUC \\
\hline & & & & & & & & & & - $\approx$ peak glucose \\
\hline [77] & 64 & $\mathrm{R}, \mathrm{DB}, \mathrm{P}$ & $\begin{array}{l}\text { Overweight and } \\
\text { increased waist } \\
\text { size } \\
\end{array}$ & 0 & $35-65$ & NA & NA & $\begin{array}{l}\text { PFE } 710 \mathrm{mg} \text { or } 1420 \mathrm{mg} \text { vs. } \\
\text { Placebo }\end{array}$ & 4 wks & $\bullet \approx \mathrm{FPG}$ \\
\hline \multirow{2}{*}{ [78] } & \multirow{2}{*}{42} & \multirow{2}{*}{$\mathrm{R}, \mathrm{DB}, \mathrm{P}$} & \multirow{2}{*}{ Overweight/obese } & \multirow{2}{*}{ NA } & \multirow{2}{*}{$30-60$} & \multirow{2}{*}{ NA } & \multirow{2}{*}{$31.8 \pm 4.5$} & \multirow{2}{*}{$\begin{array}{l}\text { PFE } 1000 \text { mg/d vs. Placebo } \\
\text { (cellulose capsules) }\end{array}$} & \multirow{2}{*}{$30 \mathrm{~d}$} & $\bullet \downarrow F P G$, \\
\hline & & & & & & & & & & $\bullet \downarrow$ FPI, HOMA-IR \\
\hline \multicolumn{11}{|c|}{ Pomegranate-based dietary supplements } \\
\hline \multirow[t]{2}{*}{ [79] } & \multirow[t]{2}{*}{20} & \multirow[t]{2}{*}{ NR, SB } & \multirow[t]{2}{*}{$\begin{array}{l}\text { Abdominal } \\
\text { obesity }\end{array}$} & 0 & $48 \pm 4$ & $10 / 10$ & $29.7 \pm 2.7$ & $\begin{array}{l}\text { Dietary supplement prepared } \\
\text { from pomegranate and grape } \\
\text { pomaces (50:50) } 10 \mathrm{~g} \text { vs. }\end{array}$ & 1 single dose & $\begin{array}{l}\text { - } \approx \text { Glucose after OGTT } \\
\text { (either administered } \\
\text { simultaneously or } 10 \mathrm{~h} \\
\text { before of the OGTT) }\end{array}$ \\
\hline & & & & & & & & Control (untreated) & & $\bullet \approx$ HOMA-IR \\
\hline
\end{tabular}

AUC: area under the curve; BMI: body mass index; bw: bodyweight; C: cross-over; CHD: coronary heart disease; COPD: chronic obstructive pulmonary disease; DB: double-blind; FPG: fasting plasma glucose; FPI: fasting plasma insulin; HOMA-IR: homeostatic model assessment of insulin resistance; HOMA \%B: homeostatic model assessment of $\beta$-cell function; MetS:
metabolic syndrome; NA: not available; NR: non-randomized; P: placebo-controlled; PE: pomegranate extract, PFE: pomegranate fruit extract; PJ: pomegranate juice; PV: pomegranate vinegar; R: randomized; SA: single arm; SB: single-blind; T2D: type 2 diabetes; d: days; wks: weeks. Placebo was not described for some of the studies. 
Pomegranate extracts were also used in several randomized clinical trials, but none of them included individuals with T2D (Table 1) $[62,77,78]$. No effects on blood glucose were observed after an acute dose in healthy subjects [62]. Studies involving longer exposures yielded mixed results. Compared to participants receiving placebo, no effect was found after supplementation in overweight subjects with increased waist size [77], while significant reductions in fasting plasma insulin and HOMA-IR were observed in obese and overweight subjects [78]. Finally, no hypoglycemic effects were found when performing a OGTT concomitantly or $10 \mathrm{~h}$ after consuming a pomegranate/grape pomace dietary supplement [79].

\section{Anti-Inflammatory, Antioxidant, and Anti-Glycation Properties of Ellagic Acid}

\subsection{Ellagic Acid and Inflammation}

Mounting evidence on human and animal models indicates the crucial role of inflammation in the onset and progression of diabetes and its related vascular complications [80,81]. In brief, diabetes is characterized by a low-grade systemic inflammation, with a permanent activation of the main inflammatory pathways (such as nuclear factor $-\mathrm{kB},(\mathrm{NF}-\mathrm{\kappa B})$ ) and the production of pro-inflammatory cytokines and chemokines (i.e., tumor necrosis factor-alpha (TNF- $\alpha$ ), interleukin (IL)-6 or IL-1 $\beta$ ), mainly by macrophages. Different anti-inflammatory pharmacological agents have been tested to reduce inflammation in diabetes. However, non-pharmacological or lifestyle interventions are gaining interest to prevent or control diabetes and its complications.

\subsubsection{In Vitro Studies}

Two in vitro studies have assessed the anti-inflammatory properties of EA. In the first one, EA $(20 \mu \mathrm{M})$ decreased the expression of cyclooxygenase-2 (COX-2) secondary to the incubation of human aortic endothelial cells with glucose $30 \mathrm{mM}$ [82]. In the second one, an extract of pomegranate flowers $(10,25,50,100 \mu \mathrm{g} / \mathrm{mL})$ decreased the expression of COX-2 in a dose-dependent manner and reduced the synthesis of nitric oxide (NO), prostaglandin E2, IL-6, IL-1 $\beta$, and TNF- $\alpha$ in lipopolysaccharide-stimulated RAW 264.7 macrophages [83].

\subsubsection{Animal Studies}

In rat models treated with high-fat and high-fructose diet [58] or STZ [39], EA decreased both circulating and cerebral TNF- $\alpha$ and IL- $6[39,58]$, as well as increased the anti-inflammatory cytokine IL-10 in hippocampus and cerebral cortex [39].

Similar results were observed after treating mice under a high-fat and high-sucrose diet with either pomegranate flower extract or pomegranate seed oil for 4 weeks [34]. Furthermore, 4-week supplementation with pomegranate peel extracts ( $6 \mathrm{mg} /$ day) counteracted the expression of COX-2, IL-1 $\beta$ and IL- 6 in both colon and visceral adipose tissue (but not in liver) in high-fat-induced hypercholesterolemia and inflammatory disorders [35]. Eight-week treatment with Chinese olive (Canarium album L.) extract (50 and $150 \mathrm{mg} / \mathrm{kg} /$ day) significantly reduced hepatic IL-6 and circulating and hepatic TNF- $\alpha$ in high-fat diet and STZ-induced diabetic rats [45].

Finally, in STZ-induced diabetic Sprague-Dawley rats, a 3-week supplementation with pomegranate juice ( $1 \mathrm{~mL} /$ day) significantly decreased systemic TNF- $\alpha$, IL-6 and NF-kB [46]. Similar results regarding TNF- $\alpha$ were observed after a 6-week supplementation (100 and $300 \mathrm{mg} / \mathrm{kg} /$ day) in STZ and nicotinamide-induced diabetic Wistar albino rats [48].

\subsubsection{Human Studies}

Two studies explored the effect of supplementation with pomegranate, as a source of EA. In the first one, a non-randomized trial conducted in 17 subjects, 4-week daily administration of 2 capsules of pomegranate polyphenols (753 mg polyphenols/capsule) did not change high-sensitivity C-reactive protein (hs-CRP) [84]. The second study was a randomized double-blind clinical trial, with a larger 
sample size, conducted in subjects with overweight or obesity. After a 30-day intervention, participants receiving dietary supplementation of pomegranate fruit extract showed significantly lower circulating hs-CRP and IL-6 levels than those allocated into the placebo group [78].

The anti-inflammatory effect of pomegranate juice have been explored in both non-randomized [65] and randomized clinical trials $[63,70,71,73,76,85]$, using a broad range of juice doses and time of exposure and including participants with either T2D [65,70,85], metabolic syndrome $[63,76]$ or arterial hypertension [71]. Consumption of pomegranate juice reduced serum hs-CRP [70,76], IL-6 [63,65] and leukocyte adhesion molecules $[63,71,85]$, even inducing anti-inflammatory changes in peripheral blood mononuclear cells (decrease in NF- $\mathrm{kB}$ and increase in sirtuin-1) [85]. Inflammation-related parameters only remained unchanged in a study conducted in healthy endurance-based athletes [73].

\subsection{Ellagic Acid and Oxidative Stress}

Oxidative stress plays a pivotal role in cellular injury from hyperglycemia [81]. High glucose levels can stimulate reactive oxygen species (ROS) production. Although a certain amount of ROS is necessary for the normal metabolic and signaling cellular processes, cells have developed powerful antioxidant systems to scavenge the surplus of ROS (or at least transform them into less reactive products) to keep redox homeostasis. Oxidative stress results when cellular antioxidant enzymatic machinery is unable to cope with an excessive production of ROS. In diabetes, oxidative stress can damage DNA (which can be assessed by 8-hydroxy-2'-deoxyguanosine, [8-OHdG] and 8-oxo-7,8-dihydro-2'-deoxyguanosine), induce lipid peroxidation (assessed by thiobarbituric acid-reactive substances (TBARS) and malondialdehyde (MDA) levels), and induce protein covalent modifications [81].

\subsubsection{In Vitro Studies}

EA $(1500 \mu \mathrm{M})$ reduced ROS production and lipid peroxidation (MDA) in cultured rat pancreatic islets [23]. Similar results were found in high glucose-induced T2D HepG2 cells, with a further increase in superoxide dismutase (SOD) activity [21]. Finally, in intact rat aortas and human aortic endothelial cells under high-glucose conditions, EA $(20 \mu \mathrm{M})$ decreased ROS production, in parallel with the decreased expression of NOX4 gene [82]. Regarding to EA-rich extracts, pomegranate peel extract reduced the MDA production of erythrocytes incubated with $\mathrm{H}_{2} \mathrm{O}_{2}$ [33]. Furthermore, pomegranate peel extract [86], as well as extracts from several EA-rich plants, such as amla [22], pea plant [36], and maire [55], increased the radical scavenging activity in the 1,1-diphenyl-2-picryl-hydrazyl (DPPH) assay. Finally, pomegranate juice sugar fraction reduced the macrophage peroxide levels in non-diabetic and STZ-induced diabetic mice in a dose-dependent manner, while increasing paraoxonase-2 (PON-2) activity [87].

\subsubsection{Animal Studies}

EA has been tested in a single study, conducted in high-fat and high-fructose diet-induced diabetic rat model [58]. A 2-week treatment $(10 \mathrm{mg} / \mathrm{kg})$ decreased circulating levels of MDA, while increasing those of glutathione (GSH, a potent antioxidant) and the activity of the antioxidant enzymes catalase (CAT) and SOD. Rats on EA displayed lower levels of several caspases and myeloperoxidase in liver, pancreas, and adipose tissue compared to those on chow [58].

Seven studies tested extracts from several parts of pomegranate (leaf, aril, peel, or flower) in non-diabetic [33] and diabetic murine models [42-44,49,50,54,88]. Studies repeatedly reported on decreased circulating and tissue (hepatic, pancreatic, cardiac, or renal) lipid peroxidation markers, mostly TBARS $[33,42,43,49,50]$. Further antioxidant properties were also documented, including decreased ROS [88], increased total antioxidant capacity and GSH levels [43,44,49], and increased (either circulating or tissue-specific) antioxidant enzymes (SOD, CAT, glutathione-S-transferase (GST), glutathione peroxidase (GPx) or glutathione reductase (GR)) $[42,43,50,54]$. Similar results concerning 
lipid peroxidation and the decrease in oxidative stress were reported after dietary inclusion of extracts from EA-rich vegetables, including amla [22], Chinese olive [45], and Mongolian oak cups [56].

Finally, the antioxidant effect of pomegranate juice has been assessed in STZ-induced diabetic murine model in four different studies [46-48,87]. Again, a decrease in lipid peroxidation (MDA [47,48] or macrophage peroxide levels [87]) and oxidative stress (increased radical scavenging activity in DPPH assay [46,87], GSH content or total antioxidant capacity $[47,48,87]$ or antioxidant enzyme activity $[47,48])$ was observed. Interestingly, the antioxidant effect of pomegranate juice resembled to the long-known antioxidant ascorbic acid [46].

\subsubsection{Human Studies}

Several forms of pomegranate have been used as a source of EA to test its antioxidant properties in human studies. Pomegranate fruit extract has been tested in three studies. In the only randomized, double-blind, and placebo-controlled trial, 30-day supplementation with pomegranate fruit extract (1000 mg/day) reduced MDA levels in overweight/obese participants [78]. Three other non-randomized studies tested 4-week supplementation with pomegranate extracts, reporting decreased lipid peroxidation $[77,84]$ and further antioxidant properties, including decreased overall serum oxidative stress and increased high-density lipoprotein (HDL)-associated PON-1 binding and activity, with a greater effect in men than in women [89].

Two randomized clinical trials explored the effects of pomegranate juice in T2D population. Both studies reported an increase in total antioxidant capacity $[75,90]$, along with decreased MDA formation [90], decreased oxidized-low-density lipoprotein (LDL) particles, and increased PON-1 activity [75]. Similarly, in a randomized, double-blind, controlled placebo trial conducted in healthy endurance-based athletes, compared to placebo, 3-week consumption of pomegranate juice ( $200 \mathrm{~mL} /$ day) blunted lipid peroxidation (formation of circulating carbonyls and MDA) secondary to exercise [73]. Finally, pomegranate juice was also tested in four non-randomized studies performed in T2D [64,65,89,91] and healthy [92] subjects. Overall, a decrease in the lipid peroxidation (reduction in circulating MDA levels $[64,91,92]$ and in intracellular peroxides in monocyte-derived macrophages [91]) was consistently observed. These trials also reported a decrease in oxidative stress, including increased PON-1 activity $[64,91]$ and decreased macrophage oxidized-LDL uptake [91].

\subsection{Ellagic Acid and Glycation}

Another way for hyperglycemia to cause injury is by fostering advanced glycation-end products (AGEs) [93]. AGEs result from the non-enzymatic addition of reducing sugars (glycation) to aminecontaining molecules (protein, lipids, or nucleotides). Carboxymethyllysine (CML) and pentosidine are two well-characterized AGE compounds, the levels of which serve as AGEs markers. AGEs induce the expression of receptors for advanced glycation end-products (RAGE). The interaction AGE-RAGE promotes ROS generation, activates NF- $\mathrm{kB}$, and therefore increases the expression of pro-inflammatory molecules. AGEs represent a major contributor for the development of diabetic complications. Its deleterious effect is dual: by the accumulation-induced direct tissue damage; and indirectly by the exacerbation of oxidative stress and inflammation. Therefore, counteracting AGEs emerge as an interesting therapeutic approach.

\subsubsection{In Vitro Studies}

EA has been repeatedly found to inhibit glycation, by means of a reduction in AGEs formation $[29,94,95]$ and by a decrease in fructose-mediated glycation of albumin [96]. Anti-glycation properties of EA (but not of EA-derived metabolites urolithin A and B) were more potent than those observed after treatment with aminoguanidine, a well-known glycation inhibitor [94]. Similarly, both pomegranate fruit [94] and peel [95] extracts showed a dose-dependent reduction in AGEs formation, having the former a higher effect than aminoguanidine [94]. Furthermore, Mongolian oak cups extracts decreased AGEs generation [29]. Finally, in a study testing the effect of commonly 
consumed juices (pomegranate, cranberry, black cherry, pineapple, apple, and Concord grape) on the fructose-mediated glycation of albumin, while pomegranate juice reduced glycation by $98 \%$, other juices only inhibited glycation by $20 \%$ [96].

\subsubsection{Animal Studies}

A single study has assessed the effects of a pomegranate fruit extract on glycation. In high-fat and high-sucrose-induced diabetic rats, 8-week treatment with pomegranate fruit extract $(1.5 \% v / v)$ reduced serum AGEs, glycoalbumin, and HbA1c in a similar manner after treatment with aminoguanidine [95]. Results concerning $\mathrm{HbA} 1 \mathrm{c}$ were further confirmed in a study testing EA in isolation, wherein STZ-induced diabetic rats were fed with chow or chow supplemented with either $0.2 \%$ or $2 \%$ of EA. After a 12-week period, inclusion of EA reduced the increase of $\mathrm{HbA1c}$ in a dose-dependent manner [97].

\subsubsection{Human Studies}

In a randomized, double-blind, placebo-controlled trial, 44 participants with T2D were randomly assigned to pomegranate juice $(250 \mathrm{~mL} /$ day) or placebo for 12 weeks. At the end of the study, no between-group differences were observed concerning the AGEs markers carboxymethyllysine and pentosidine [90].

\section{Ellagic Acid and Complications of Diabetes}

\subsection{Microvascular Complications}

\subsubsection{Diabetic Kidney Disease}

Diabetic kidney disease (DKD) is present in approximately $40 \%$ of patients with T2D, being the leading cause of chronic kidney disease worldwide [98]. It accounts from minor albuminuria to advanced kidney dysfunction with need of renal replacement therapy [98]. Although some glucose-lowering drugs have recently shown promising results in the prevention and management of this chronic complication [99], common antioxidant agents have also been associated with an improvement in early renal damage [100]. Thus, antioxidants could be used as an additive treatment for the management of this prevalent complication associated with pharmacological intervention.

Data on EA and DKD are limited to experimental research (Table 2). Animal studies were conducted in STZ-induced diabetes [41,97,101-104] or in high-fat diet combined with low-dose STZ [105]. Four studies tested EA at different doses and with different times of exposure [97,101,104,105]. These studies consistently reported on strongly nephroprotective properties, including amelioration of renal histopathology alterations [104,105]; decreased renal inflammation [101,104,105] secondary to NF-KB inhibition [105]; decreased oxidative stress/lipid peroxidation and increased enzymatic antioxidant activity [105]; reduced fibrosis markers [97,105]; decreased renal AGEs accumulation [97,101]; and inhibition of the polyol pathway in the kidney [101]. All these effects translated into the improvement of the common laboratory kidney function parameters, namely decreased creatinine, or blood urea nitrogen (BUN), increased creatinine clearance, and reduced proteinuria. Interestingly, one study found renal effects of EA akin to those observed with the nephroprotective drug irbesartan [104]. A similar protection was observed when using pomegranate leave extract [103], pomegranate peel extract-stabilized gold nanoparticles [41], or pomegranate juice [102] as exposure.

In vitro experiments further confirmed the EA anti-inflammatory properties on cultured rat proximal tubular epithelial cells challenged to pro-inflammatory stimuli. One study found that EA decreased the high-glucose-induced NF- $\kappa B$ activation and reduced the levels of the inflammatory cytokines IL-1 $\beta$, IL- 6 , and TNF- $\alpha$ [105]. In line with this, a second study found that EA inhibited the TLR4/NF-kB inflammatory pathway activated by the administration of lipopolysaccharide [104]. 


\subsubsection{Retinopathy}

Diabetic retinopathy (DR) is present in roughly $40 \%$ of the individuals with diabetes. Overall, DR is the most frequent cause of blindness among adults aged 20-74 years in developed countries [106]. Although glucose control is strongly associated with the prognosis of this complication, some recent studies have linked some dietary factors (independently of glucose metabolism) with the protection against DR [107,108].

Data on EA and DR is limited to experimental research (Table 2). Two studies conducted in STZ-induced diabetic rats reported protective effects of EA. In the first one, compared to rats fed chow, those fed with EA for 12 weeks showed reductions in the retinal AGE carboxymethyllysine along with activation of receptor of AGEs [109]. EA also reduced pro-apoptotic, neovascularization, and gliosis markers, increased retinal thickness, and improved electroretinogram abnormalities [109]. In the second one, 10-week dietary supplementation with pomegranate juice reduced retinal 8-OHdG and MDA, along with higher GSH and GSH-glutathione peroxidase activities [110].

Table 2. Animal studies assessing the effects of EA on microvascular diabetic complications.

\begin{tabular}{|c|c|c|c|c|}
\hline Reference & Study Model & Interventions & Duration & Main Results \\
\hline & & Diabetic Kidney & Disease & \\
\hline \multirow{6}{*}{ [41] } & \multirow{6}{*}{$\begin{array}{l}\text { STZ-induced diabetic } \\
\text { mice (BALB/c), males }\end{array}$} & \multirow{6}{*}{$\begin{array}{c}\text { Control vs. } \\
\text { PPE-AuNP } 5 \\
\text { (15 or } 25 \mathrm{mg} / \mathrm{kg} \text { every } \\
\text { 2nd day) }\end{array}$} & \multirow{6}{*}{$10 \mathrm{~d}$} & - $\downarrow$ renal histopathology alterations \\
\hline & & & & $\begin{array}{l}\text { - } \downarrow \text { renal fibrosis markers (TGF- } \beta \text { and } \\
\text { Col IV) }\end{array}$ \\
\hline & & & & $\begin{array}{l}-\downarrow \text { renal oxidative stress }(\downarrow \text { ROS, } \downarrow \text { LPO, } \\
\downarrow \text { nitrite; } \downarrow \text { MAPK pathway; } \downarrow \text { NOX4 } \\
\text { and p47phox expression; } \uparrow S O D, \uparrow G S H, \\
\uparrow N r f 2 \text { activation) }\end{array}$ \\
\hline & & & & $\begin{array}{l}-\downarrow \text { renal inflammation }(\downarrow N F-\kappa B \text { and } \\
\text { STAT3 pathways: IL- } 1 \beta, \text { IFN- } \gamma \text {, IL-6, } \\
\text { IL-10, TNF- } \alpha, \text { COX2) }\end{array}$ \\
\hline & & & & - $\downarrow$ renal AGEs and RAGE \\
\hline & & & & - $\downarrow$ urinary urea and creatinine \\
\hline \multirow{6}{*}{ [97] } & \multirow{6}{*}{$\begin{array}{l}\text { STZ-induced diabetic } \\
\text { rats (Wistar), males }\end{array}$} & \multirow{6}{*}{$\begin{array}{l}\text { Control vs. } \\
\text { EA }(0.2 \text { or } 2 \%)\end{array}$} & \multirow{6}{*}{12 wks } & $\begin{array}{l}\text { - } \downarrow \text { protein glycation in glomeruli (IgG } \\
\text { cross-linking, CML accumulation) }\end{array}$ \\
\hline & & & & - $\downarrow$ renal RAGE expression \\
\hline & & & & - $\downarrow$ renal TGF- $\beta$ expression \\
\hline & & & & - $\downarrow$ accumulation of ECM \\
\hline & & & & $\begin{array}{l}\text { - } \uparrow \text { podocyte specific markers } \\
\text { (podocin, nephrin) }\end{array}$ \\
\hline & & & & - $\downarrow$ UACR and urinary urea \\
\hline \multirow{5}{*}{ [101] } & \multirow{5}{*}{$\begin{array}{l}\text { STZ-induced diabetic } \\
\text { mice }(\text { Balb/cA), males }\end{array}$} & \multirow{5}{*}{$\begin{array}{c}\text { Control } \\
(\mathrm{CA}, 2.5 \text { or } 5 \%) \text { vs. } \\
\text { EA }(2.5 \text { or } 5 \%)\end{array}$} & \multirow{5}{*}{$12 \mathrm{wks}$} & $\begin{array}{l}\text { - } \downarrow \text { renal AGEs (CML, pentosidine, } \\
\text { sorbitol, fructose) }\end{array}$ \\
\hline & & & & $\begin{array}{l}\text { - } \downarrow \text { renal polyol pathway ( } \downarrow \text { AR and } \\
\text { SDH activity) }\end{array}$ \\
\hline & & & & $\begin{array}{l}-\downarrow \text { renal inflammation markers (IL- } 1 \beta \text {, } \\
\text { IL-6, TNF- } \alpha, \text { MCP-1) }\end{array}$ \\
\hline & & & & - $\downarrow$ serum BUN \\
\hline & & & & 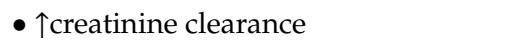 \\
\hline \multirow[b]{2}{*}{ [102] } & \multirow{2}{*}{$\begin{array}{l}\text { STZ-induced diabetic } \\
\text { rats (Wistar), +/-Ang } \\
\text { II), males }\end{array}$} & \multirow{2}{*}{$\begin{array}{l}\text { Control vs. } \\
\text { PJ }(100 \text { or } \\
300 \mathrm{mg} / \mathrm{kg} / \mathrm{d})\end{array}$} & \multirow[b]{2}{*}{4 wks } & $\begin{array}{l}\text { • } \downarrow \text { renal histopathology tubular } \\
\text { alterations (no mesangial protection) }\end{array}$ \\
\hline & & & & $\begin{array}{l}\text { - } \downarrow \text { renal oxidative stress/lipid } \\
\text { peroxidation ( } \downarrow \text { MDA, } \uparrow G S H, \\
\uparrow S O D, \uparrow C A T)\end{array}$ \\
\hline
\end{tabular}


Table 2. Cont.

\begin{tabular}{|c|c|c|c|c|}
\hline Reference & Study Model & Interventions & Duration & Main Results \\
\hline \multirow{5}{*}{ [103] } & \multirow{5}{*}{$\begin{array}{l}\text { STZ-induced diabetic } \\
\text { rats (Wistar), either } \\
\text { sex }\end{array}$} & \multirow{5}{*}{$\begin{array}{l}\text { Control vs. } \\
\text { PLE }(50,100 \text { or } \\
200 \mathrm{mg} / \mathrm{kg} / \mathrm{d})\end{array}$} & \multirow{5}{*}{4 wks } & $\begin{array}{l}\text { - } \downarrow \text { renal histopathology alterations } \\
\text { and inflammatory cells infiltration }\end{array}$ \\
\hline & & & & $\begin{array}{l}-\downarrow \text { renal oxidative stress/peroxidation } \\
(\downarrow \mathrm{MDA}, \uparrow \mathrm{GSH}, \uparrow S O D, \uparrow C A T)\end{array}$ \\
\hline & & & & - \albuminuria \\
\hline & & & & - $\downarrow$ Serum BUN and creatinine \\
\hline & & & & - $\uparrow$ creatinine clearance \\
\hline \multirow{5}{*}{ [104] } & \multirow{5}{*}{$\begin{array}{l}\text { STZ-induced diabetic } \\
\text { mice (ICR), males }\end{array}$} & \multirow{5}{*}{$\begin{array}{l}\text { Control vs. } \\
\text { EA }(50,100 \text { or } \\
150 \mathrm{mg} / \mathrm{kg} / \mathrm{d}) \text { vs. } \\
\text { IRB }(180 \mathrm{mg} / \mathrm{kg} / \mathrm{d})\end{array}$} & \multirow{5}{*}{4 wks } & $\begin{array}{l}-\downarrow \text { renal histopathology alterations } \\
\text { and inflammatory cells infiltration } \\
(\approx I R B)\end{array}$ \\
\hline & & & & - $\downarrow$ renal inflammation $(\downarrow$ TLR4/NF- $k B)$ \\
\hline & & & & - $\downarrow$ albuminuria $(\approx \mathrm{IRB})$ \\
\hline & & & & - $\downarrow$ serum creatinine $(\approx \mathrm{IRB})$ \\
\hline & & & & 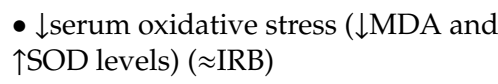 \\
\hline \multirow{7}{*}{ [105] } & \multirow{7}{*}{$\begin{array}{c}\text { HFD/low-dose } \\
\text { STZ-induced type } 2 \\
\text { diabetic rats (Wistar), } \\
\text { males }\end{array}$} & \multirow{7}{*}{$\begin{array}{c}\text { Control vs. } \\
\text { EA }(20 \text { or } 40 \mathrm{mg} / \mathrm{kg} / \mathrm{d})\end{array}$} & \multirow{7}{*}{$16 \mathrm{wks}$} & $\begin{array}{l}\text { - } \downarrow \text { renal histopathology tubular } \\
\text { alterations (no mesangial protection) }\end{array}$ \\
\hline & & & & - $\downarrow$ renal PAS accumulation \\
\hline & & & & $\begin{array}{l}\text { - } \downarrow \text { renal expression of NF- } \mathrm{kBp} 65 \text {, } \\
\text { TGF- } \beta \text { and fibronectin }\end{array}$ \\
\hline & & & & $\begin{array}{l}\text { - } \downarrow \text { serum inflammatory cytokines } \\
(\mathrm{IL}-1 \beta, \text { IL-6, TNF- } \alpha \text { ) }\end{array}$ \\
\hline & & & & $\begin{array}{l}\text { - } \downarrow \text { renal oxidative stress/peroxidation } \\
(\downarrow \text { MDA, } \uparrow G S H, \uparrow \text { antioxidant } \\
\text { enzymes activity) }\end{array}$ \\
\hline & & & & - $\downarrow$ serum creatinine, BUN, proteinuria \\
\hline & & & & - $\uparrow$ creatinine clearance \\
\hline \multicolumn{5}{|l|}{ Retinopathy } \\
\hline \multirow{6}{*}{ [109] } & \multirow{6}{*}{$\begin{array}{l}\text { STZ-induced diabetic } \\
\text { rats (Wistar-NIN), } \\
\text { males }\end{array}$} & \multirow{6}{*}{$\begin{array}{l}\text { Control vs. } \\
\text { EA }(0.2 \text { or } 2 \%)\end{array}$} & \multirow{6}{*}{$12 \mathrm{wks}$} & - $\uparrow$ retinal thickness \\
\hline & & & & - $\downarrow$ retinal AGE (CML) and RAGE \\
\hline & & & & - $\downarrow$ retinal pro-apoptotic markers (Bax) \\
\hline & & & & $\begin{array}{l}\text { - } \downarrow \text { retinal neovascularization markers } \\
\text { (HIF- } 1 \alpha \text { and VEGF) }\end{array}$ \\
\hline & & & & - $\downarrow$ retinal gliosis markers (GFAP) \\
\hline & & & & $\begin{array}{l}\text { - Improvement electroretinogram } \\
\text { abnormalities }\end{array}$ \\
\hline \multirow{3}{*}{ [110] } & \multirow{3}{*}{$\begin{array}{c}\text { STZ-induced } \\
\text { diabetic rats } \\
\text { (Sprague-Dawley), } \\
\text { either sex }\end{array}$} & \multirow{3}{*}{$\begin{array}{l}\text { Control vs. } \\
\mathrm{PJ}(100 \mu \mathrm{L} / \mathrm{d})\end{array}$} & \multirow{3}{*}{$10 \mathrm{wks}$} & $\begin{array}{l}\text { - } \downarrow \text { renal histopathology tubular } \\
\text { alterations (no mesangial protection) }\end{array}$ \\
\hline & & & & $\begin{array}{l}\text { - } \downarrow \text { retinal oxidative stress/lipid } \\
\text { peroxidation }(\downarrow 8 \mathrm{OHdG}, \downarrow \mathrm{MDA} \text {, } \\
\uparrow \mathrm{GSH}, \uparrow \mathrm{GSH}-\mathrm{Px})\end{array}$ \\
\hline & & & & - $\downarrow$ retinal eNOS and P65 staining \\
\hline
\end{tabular}

8OHdG: 8-hydroxy-2'-deoxyguanosine; AGEs: advanced glycation end products; AngII: angiotensin II; AR: aldose reductase; BUN: blood urea nitrogen; EA: ellagic acid; ECM: extracellular matrix; CA: caffein acid; CAT: catalase; CML: carboxymethyllysine; Col: Collagen; d: days; GSH: glutathione; GSH-Px: glutathione peroxidase; HFD: high-fat diet; HIF-1 $\alpha$ : hypoxia-inducible factor- $1 \alpha$; IL: interleukin; IL-6: interleukin-6; IFN- $\gamma$ : interferon- $\gamma$; IRB: irbesartan; LPO: lipoperoxides; MCP-1: monocyte chemoattractant protein-1; MDA: malondialdehyde; NF- $\mathrm{KB}$ : nuclear factor-kB; PAS: periodic acid-Schiff; PLE: pomegranate leave extract; PPE-AuNP: pomegranate peel extract-stabilized gold nanoparticles; RAGE: receptor of AGE; SDH: sorbitol dehydrogenase; SOD: superoxide dismutase; STZ: streptozotocin; TGF- $\beta$ : transforming growth factor- $\beta$; TNF- $\alpha$ : tumor necrosis factor- $\alpha$; UACR: urinary albumin-to-creatinine ratio; VEGF: vascular endothelial growth factor; wks: weeks. 


\subsection{Macrovascular Complications}

Cardiovascular disease is the leading cause of mortality among T2D patients [111]. In fact, this population segment has consistently shown an accelerated atherosclerosis compared to their non-diabetic counterparts [112,113]. Furthermore, and additionally to the increased risk of coronary heart disease, T2D individuals also show a specific heart phenotype (so-called diabetic cardiomyopathy), which increases the lifetime risk of heart failure [114]. The number of classical and non-classical risk factors associated with these macrovascular complications is increasing [115], some of them showing even a stronger relationship than glycemia per se [116]. In this sense, inflammation is thought to be an important mediator of this increased cardiovascular risk [117]. Thus, dietary interventions with a multifactorial approach, combining glucose-lowering, anti-inflammatory, or antioxidant properties, could be useful in the prevention of this chronic complication.

\subsubsection{Atherosclerosis}

Four different animal models have been used to investigate the vasoprotective properties of EA (Table 3). In Apolipoprotein E-deficient mice (at a high risk of atherosclerosis but without obesity or diabetes), 3-month dietary supplementation with either pomegranate juice or pomegranate peel extracts ameliorated atherosclerotic lesion area in the aorta [118]. In a study conducted in obese Zucker rats (a model of metabolic syndrome), compared to rats fed chow, 5-week supplementation with either pomegranate juice or a pomegranate fruit extract induced significant changes in the arterial function, including decreased expression of vascular inflammation markers, increased plasma nitrate and nitrite (NOx) levels, increased endothelial NO synthase (eNOS) expression, and increased arterial vasodilatation in response to acetylcholine [119]. The latter finding was replicated in high-carbohydrate and high-fat diet-induced metabolic syndrome rats supplemented with EA for 8 weeks, along with an increase in aortic contractile response to noradrenalin [120]. Finally, in STZ-induced diabetic rats, compared to rats fed control diet, 12-week supplementation with EA reduced medial thickness enlargement, lipid deposition in the aortic arch, and vessel proliferation markers [121].

Table 3. Animal and human studies assessing the effects of EA on macrovascular diabetic complications.

\begin{tabular}{|c|c|c|c|c|}
\hline Reference & Study Model & Interventions & Duration & Main Results \\
\hline \multicolumn{5}{|c|}{ Atherosclerosis, animal studies } \\
\hline \multirow{10}{*}[118]{} & \multirow{10}{*}{$\begin{array}{l}\text { ApoE-deficient mice, } \\
\text { males }\end{array}$} & \multirow{5}{*}{$\begin{array}{c}\text { Control vs. } \\
\text { PPE or PAE or PFE or PSE } \\
(200 \mu \mathrm{g} \mathrm{GAE} / \mathrm{d})\end{array}$} & \multirow{5}{*}{$13 \mathrm{wks}$} & $\begin{array}{l}\text { - } \downarrow \text { atherosclerotic lesion size } \\
\text { (no effect in PAE or PSE) }\end{array}$ \\
\hline & & & & $\begin{array}{l}\text { - } \downarrow \text { serum lipoperoxides (PFE } \\
\text { and PAE) }\end{array}$ \\
\hline & & & & - $\uparrow$ serum PON1 activity (only PAE) \\
\hline & & & & $\begin{array}{l}\text { - } \downarrow \text { macrophage oxidized-LDL } \\
\text { uptake (only PPE) }\end{array}$ \\
\hline & & & & $\begin{array}{l}\text { - } \uparrow \text { HDL-cholesterol efflux } \\
\text { (only PAE) }\end{array}$ \\
\hline & & \multirow{5}{*}{$\begin{array}{l}\text { Control vs. } \\
\text { PJ }(200 \mu g \text { GAE/d) }\end{array}$} & \multirow{5}{*}{$13 \mathrm{wks}$} & - $\downarrow$ atherosclerotic lesion size \\
\hline & & & & - $\downarrow$ serum lipoperoxides \\
\hline & & & & - $\uparrow$ serum PON1 activity \\
\hline & & & & $\begin{array}{l}\text { - } \downarrow \text { macrophage LDL and } \\
\text { oxidized-LDL uptake }\end{array}$ \\
\hline & & & & - $\uparrow$ HDL-cholesterol efflux \\
\hline \multirow{2}{*}{ [119] } & \multirow{2}{*}{$\begin{array}{l}\text { Obese Zucker rats, } \\
\text { females }\end{array}$} & $\begin{array}{l}\text { Control (atherogenic diet) vs. } \\
\text { PFE }(30 \mu \mathrm{L} / \mathrm{d}) \text { - supplemented } \\
\text { atherogenic diet }\end{array}$ & $5 \mathrm{wks}$ & $\begin{array}{l}\text { - } \uparrow \text { vasodilatation in response to } \\
\text { acetylcholine }\end{array}$ \\
\hline & & $\begin{array}{l}\text { Control (atherogenic diet) vs. } \\
\text { PJ (30 } \mu \mathrm{L} / \mathrm{d}) \text { - supplemented } \\
\text { atherogenic diet }\end{array}$ & $5 \mathrm{wks}$ & $\begin{array}{l}\text { - } \uparrow \text { vasodilatation in response to } \\
\text { acetylcholine }\end{array}$ \\
\hline
\end{tabular}


Table 3. Cont.

\begin{tabular}{|c|c|c|c|c|}
\hline Reference & Study Model & Interventions & Duration & Main Results \\
\hline \multirow{2}{*}{ [120] } & \multirow{2}{*}{$\begin{array}{l}\text { High-carbohydrate, } \\
\text { HFD-induced MetS } \\
\text { rats (Wistar), males }\end{array}$} & \multirow{2}{*}{$\begin{array}{l}\text { Control vs. } \\
\text { EA }(0.8 \mathrm{~g} / \mathrm{kg} \text { food })\end{array}$} & \multirow{2}{*}{8 wks } & $\begin{array}{l}\text { - } \uparrow \text { vasodilatation in response } \\
\text { to acetylcholine }\end{array}$ \\
\hline & & & & $\begin{array}{l}\text { - } \uparrow \text { aortic contractile in response } \\
\text { to noradrenalin }\end{array}$ \\
\hline \multirow{4}{*}{ [121] } & \multirow{4}{*}{$\begin{array}{l}\text { STZ-induced diabetic } \\
\text { rats (NIN-Wistar), } \\
\text { males }\end{array}$} & \multirow{4}{*}{ Control vs. EA ( $2 \%)$} & \multirow{4}{*}{$12 \mathrm{wks}$} & - $\downarrow$ medial layer thickness \\
\hline & & & & - $\downarrow$ lipid accumulation \\
\hline & & & & - $\downarrow$ deposition of collagen \\
\hline & & & & $\begin{array}{l}\text { - } \downarrow \text { cyclin D1 expression in media } \\
\text { (SMC proliferation marker) }\end{array}$ \\
\hline \multicolumn{5}{|c|}{ Atherosclerosis, human studies } \\
\hline [63] & $\begin{array}{l}\text { MetS, adolescents } \\
\quad(\mathrm{n}=30)\end{array}$ & $\begin{array}{c}\text { PJ }(240 \mathrm{~mL} / \mathrm{d}) \text { vs. grape juice } \\
(18 \mathrm{~mL} / \mathrm{kg} / \mathrm{d})\end{array}$ & 4 wks & - $\uparrow \mathrm{FMD}$, both interventions \\
\hline [73] & $\begin{array}{l}\text { Hypertension } \\
\quad(\mathrm{n}=20)\end{array}$ & $\begin{array}{l}\text { Placebo (water) vs. } \\
\text { PJ ( } 150 \mathrm{~mL} / \mathrm{d})\end{array}$ & 2 wks & - no improvements in FMD \\
\hline \multicolumn{5}{|c|}{ Cardiopathy, animal studies } \\
\hline \multirow{5}{*}{ [30] } & \multirow{5}{*}{$\begin{array}{l}\text { Myocardial infarction } \\
\text { in STZ-induced } \\
\text { diabetic rats (Wistar), } \\
\text { males }\end{array}$} & \multirow{5}{*}{$\begin{array}{c}\text { Control vs. } \\
\text { Terminalia arjuna extract } \\
(500 \mathrm{mg} / \mathrm{kg} / \mathrm{d}) \text { or vildagliptin } \\
(10 \mathrm{mg} / \mathrm{kg} / \mathrm{d})\end{array}$} & \multirow{5}{*}{4 wks } & - $\downarrow$ focal myofiber loss \\
\hline & & & & - $\downarrow$ inflammation \\
\hline & & & & - $\downarrow$ necrosis \\
\hline & & & & - \edema \\
\hline & & & & $\begin{array}{l}\text { - } \downarrow \text { cardiac parameters (CPK-MB, } \\
\text { but less than vildagliptin) }\end{array}$ \\
\hline \multirow{5}{*}{ [120] } & \multirow{5}{*}{$\begin{array}{l}\text { High-carbohydrate, } \\
\text { HFD-induced MetS } \\
\text { rats (Wistar), males }\end{array}$} & \multirow{5}{*}{$\begin{array}{c}\text { Control vs. } \\
\text { EA }(0.8 \mathrm{~g} / \mathrm{kg} \text { food })\end{array}$} & \multirow{5}{*}{8 wks } & $\begin{array}{l}\text { - } \downarrow \text { cardiac infiltration of } \\
\text { inflammatory cells }\end{array}$ \\
\hline & & & & - $\downarrow$ cardiac collagen deposition \\
\hline & & & & $\begin{array}{l}\text { - } \uparrow \text { cardiac hemodynamic } \\
\text { performance ( } \uparrow E F ; \downarrow \text { LVIDs; } \\
\downarrow \text { systolic volume, } \downarrow \text { fractional } \\
\text { shortening; } \downarrow \text { estimated LV mass; } \\
\downarrow \text { LV diastolic stiffness) }\end{array}$ \\
\hline & & & & - $\downarrow$ cardiac NF- $\mathrm{kB}$ expression \\
\hline & & & & - $\uparrow$ cardiac CPT-1 expression \\
\hline \multirow{3}{*}{ [122] } & \multirow{3}{*}{$\begin{array}{l}\text { STZ-induced diabetic } \\
\text { mice }(\text { Balb/c), males }\end{array}$} & \multirow{3}{*}{ Control vs. EA ( $2 \%)$} & \multirow{3}{*}{12 wks } & $\begin{array}{l}\text { - } \downarrow \text { cardiac triglyceride content } \\
\text { (but not cholesterol) }\end{array}$ \\
\hline & & & & $\begin{array}{l}\text { - } \downarrow \text { cardiac inflammation (IL-1 } \beta \text {; } \\
\text { IL-6; TNF- } \alpha \text {; MCP-1) }\end{array}$ \\
\hline & & & & $\begin{array}{l}\text { - } \downarrow \text { cardiac oxidative stress }(\downarrow M D A, \\
\downarrow R O S ; \uparrow G S H, \uparrow C A T, \uparrow S O D, \\
\uparrow G S H-P x)\end{array}$ \\
\hline \multirow[b]{2}{*}{ [123] } & \multirow{2}{*}{$\begin{array}{l}\text { Zucker diabetic fatty } \\
\text { rats, males }\end{array}$} & \multirow{2}{*}{$\begin{array}{c}\text { Control vs. } \\
\text { PFE }(500 \mathrm{mg} / \mathrm{kg} / \mathrm{d})\end{array}$} & \multirow[b]{2}{*}{$6 \mathrm{wks}$} & $\begin{array}{l}\text { - } \downarrow \text { cardiac triglyceride content (but } \\
\text { not cholesterol) }\end{array}$ \\
\hline & & & & $\begin{array}{l}\text { - } \downarrow \text { abnormal cardiac upregulation } \\
\text { lipogenic genes (FATP, PPAR } \alpha \text {, } \\
\text { CPT-1, ACO, AMPK } \alpha 2)\end{array}$ \\
\hline \multirow{3}{*}{ [124] } & \multirow{3}{*}{$\begin{array}{l}\text { Zucker diabetic fatty } \\
\text { rats, males }\end{array}$} & \multirow{3}{*}{$\begin{array}{c}\text { Control vs. } \\
\text { PFE }(500 \mathrm{mg} / \mathrm{kg} / \mathrm{d})\end{array}$} & \multirow{3}{*}{6 wks } & $\begin{array}{l}\text { - } \downarrow \text { interstitial and perivascular } \\
\text { collagen deposit }\end{array}$ \\
\hline & & & & $\begin{array}{l}\text { - } \downarrow \text { cardiac fibrosis markers } \\
\text { (fibronectin, collagen I and III, } \\
\text { ET-1 and } \mathrm{ET}_{\mathrm{A}} \text { ) }\end{array}$ \\
\hline & & & & - $\downarrow N F-\kappa B$ pathway activation \\
\hline
\end{tabular}


Table 3. Cont.

\begin{tabular}{|c|c|c|c|c|}
\hline Reference & Study Model & Interventions & Duration & Main Results \\
\hline \multirow{3}{*}[125]{} & \multirow{3}{*}{$\begin{array}{l}\text { STZ-induced diabetic } \\
\text { rats (Wistar), males }\end{array}$} & \multirow{3}{*}{$\begin{array}{l}\text { Control vs. } \\
\text { Urolithin A or Urolithin B } \\
(2.5 \mathrm{mg} / \mathrm{kg} / \mathrm{d})\end{array}$} & \multirow{3}{*}{3 wks } & $\begin{array}{l}\text { - } \uparrow \text { cardiac hemodynamic } \\
\text { performance, specially urolithin B } \\
\left(\uparrow \mathrm{LVSP} ; \uparrow+\mathrm{dP} / \mathrm{dt}_{\mathrm{max}}, \downarrow \mathrm{IVCT},\right. \\
\downarrow \text { Tcycle) }\end{array}$ \\
\hline & & & & $\begin{array}{l}\text { - Improvement of cardiomyocyte } \\
\text { mechanics and calcium transients }\end{array}$ \\
\hline & & & & $\begin{array}{l}\text { - } \downarrow \text { fractalkine (cardiac } \\
\text { pro-inflammatory cytokine) }\end{array}$ \\
\hline \multicolumn{5}{|c|}{ Cardiopathy, human studies } \\
\hline$[66]$ & $\begin{array}{l}\text { CHD and myocardial } \\
\text { ischemia }(n=45)\end{array}$ & $\begin{array}{l}\text { Placebo vs. } \\
\text { PJ }(240 \mathrm{~mL} / \mathrm{d})\end{array}$ & 13 wks & $\begin{array}{l}\text { - } \downarrow \text { stress-induced ischemia } \\
\text { (in myocardial perfusion } \\
\text { single-photon emission computed } \\
\text { tomographic technetium- } 99 \mathrm{~m} \\
\text { tetrofosmin scintigraphy) }\end{array}$ \\
\hline
\end{tabular}

ACO: acyl-CoA oxidase; AMPK: 5'-AMP-activated protein kinase; ApoE: apolipoprotein E; CAT: catalase; dP/dtmax: maximal rate of ventricular pressure rise; $\mathrm{CHD}$ : coronary heart disease; $\mathrm{CPK}-\mathrm{MB}$ : creatinine phosphokinase-MB; CPT-1: carnitine palmitoyltransferase 1; EA: ellagic acid; EF: ejection fraction; ET: endothelin; FATP: fatty acid transport protein; FMD: flow-mediated dilatation; GAE: gallic acid equivalents; GSH; glutathione; GSH-Px: glutathione peroxidase; HDL: high-density lipoprotein; HFD: high-fat diet; IL: interleukin; IVCT: isovolumic contraction time; LDL: low-density lipoprotein; LV: left ventricular; LVIDs: left ventricular internal diameter during systole; LVSP: left ventricular systolic pressure; MCP-1: monocyte chemoattractant protein-1; MDA: malondialdehyde; MetS: metabolic syndrome; NF-kB: nuclear factor-kB; PAE: pomegranate arils extract; PFE: pomegranate flowers extract; PJ: pomegranate juice; PON1: paraoxonase 1; PPAR $\alpha$ : peroxisome proliferator-activated receptor- $\alpha$; PPE: pomegranate peel extract; PSE: pomegranate seed extract; ROS: reactive oxygen species; SMC: smooth muscle cell; SOD: superoxide dismutase; Tcycle: total cycle duration; TNF- $\alpha$ : tumor necrosis factor- $\alpha$; d: days; wks: weeks.

Regarding to in vitro assays, EA blunted platelet-derived growth factor-BB (PDGF-BB)-induced proliferation of primary cultures of rat aortic smooth muscle cells, by blocking PDGF receptor- $\beta$ tyrosine phosphorylation, the generation of intracellular ROS, and extracellular signal-regulated kinase 1/2 (ERK1/2) downstream activation [121]. Similarly, addition of EA also corrected the impaired vasodilation of rat aortas secondary to a high-glucose environment [82]. Finally, both pomegranate juice and several pomegranate extracts decreased the intracellular cholesterol biosynthesis rate and the uptake of native LDL and oxidized-LDL in mouse peritoneal and J774A.1 macrophages, while increasing HDL-mediated cholesterol efflux capacity [118].

Such overall anti-atherosclerotic effect was not observed in humans, although clinical research on the topic is still fragmentary (Table 3). In a randomized-controlled trial conducted in adolescents with metabolic syndrome, 4-week dietary supplementation with pomegranate juice improved flowmediated dilatation, yet at a similar level than the comparator (grape juice) [63]. In the other randomized trial performed to date, no significant differences were observed regarding flow-mediated dilatation in hypertensive patients supplemented with either pomegranate juice or water for 2 weeks [71].

\subsubsection{Cardiopathy}

Both EA and some pomegranate extracts ameliorate several diabetic-related cardiac abnormalities in murine models (Table 3). Eight-week dietary EA reversed the cardiac effects induced by an 8-week high-carbohydrate and high-fat diet, including cardiac fibrosis, inflammatory cell infiltration, and impaired ventricular function [120]. Similarly, STZ-induced diabetic mice fed an EA-supplemented diet for 12 weeks showed lower cardiac levels of triglycerides and markers of oxidation and inflammation in comparison to mice fed chow [122]. Lower cardiac triglyceride levels and lower collagen deposit at left ventricular area and coronary artery media area were also observed in Zucker diabetic rats after a 6-week supplementation with pomegranate flower extract [123,124]. In STZ-induced diabetic rats, 3-week daily intraperitoneal injection of urolithin A or urolithin B (both resulting from the gastrointestinal metabolization of EA) reduced by approximately $30 \%$ the myocardial expression 
of fractalkine (a pro-inflammatory cytokine), while improving myocardium calcium transients and cardiac hemodynamic performance [106]. Finally, the cardioprotective effects of an extract of arjun tree were tested in the experimental model of myocardial infarction co-existing with diabetes. To this end, STZ-induced diabetic rats were treated with the extract for 4 weeks prior to isoproterenol-induced myocardial infarction. Forty-eight hours after the ischemic insult, rats which had been fed a diet with the extract showed lower degree of myocardial edema, inflammation, and necrosis compared to rats fed chow [30]. An in vitro assay supported the cardioprotective effect of EA observed in animals. Isolated myocardial tissue preparations from EA-treated rats showed improvements in both calcium transients and contractile function [126].

Incipient clinical research on the topic reinforced these cardioprotective properties (Table 3). In the single randomized, controlled trial conducted to date, 45 patients with coronary ischemic disease and myocardial ischemia (24\% with diabetes) received either pomegranate juice or placebo drink with a similar caloric content for three months. Those patients allocated to the EA-rich food showed a decrease in stress-induced ischemia compared with the baseline, while the opposite was observed in the placebo group [66].

\subsection{Neurologic-Related Complications of Diabetes}

Even though diabetic chronic complications have been classically divided into micro- and macrovascular ones, compelling evidence suggests that T2D is also associated with other non-traditional manifestations [127]. Among them, neurological-related complications involve a high socioeconomic cost [127]. Research is needed to ascertain whether certain dietary interventions would act synergistically with glucose-lowering drugs, which have already shown promising preliminary results [128].

Five studies assessed the protective effect of EA on diabetic-related neurological manifestations. In the first one, STZ-induced diabetic rats treated with EA ( $50 \mathrm{mg} / \mathrm{kg} /$ day) for 3 weeks showed lower levels of oxidative stress markers in the brain or the sciatic nerve (decrease in total oxidant status, MDA, and NO) and higher activity of antioxidant enzymes when compared with rats fed chow. EA-treated animals showed lower microhemorrhagic focus with a damaged blood vessel, neuronal hydropic degenerative changes, and disorganized fibrillary degenerative changes compared to untreated rats [129]. Similar results were found in a high-fat and high-fructose diet-induced diabetic rat model, in which a 2-week treatment with EA $(10 \mathrm{mg} / \mathrm{kg} /$ day $)$ decreased brain levels of myeloperoxidase and several caspases [58]. Two studies focused on functional aspects [39,130]. In STZ-induced diabetic rats, 8 -week supplementation with ground powder of pomegranate flowers at different doses $(300,400$, and $500 \mathrm{mg} / \mathrm{kg} /$ day) dose-dependently ameliorated the cognitive deficits in diabetic rats (as assessed by the Morris water maze test), restoring it towards those observed in non-diabetic ones [130]. In a similar study, 8-week dietary EA ( $50 \mathrm{mg} / \mathrm{kg} /$ day) attenuated anxiety/depression-like behavior, improved behavioral deficits, and prevented neuronal loss [39]. Finally, administration of an extract of dried pomegranate rinds was found to improve peripheral nerve function (and the ensuing antinociceptive activity) in alloxan-induced diabetic mice [54].

\section{Conclusions}

In conclusion, experimental research fostered the notion of dietary EA as a potential agent to limit the burden of diabetes, but clinical evidence is less established. Many in vitro and animal studies explored the hypoglycemic effect of EA. In addition to improvements in both insulin sensitivity and secretion, there is evidence for the benefits of EA in decreasing postprandial hyperglycemia (via inhibition of intestinal $\alpha$-glucosidase activity) and, to a lesser extent, the modulation of incretin effect. However, evidence on the favoring EA-rich dietary sources (mostly pomegranate juice) in better glucose control is much weaker in humans (Table 1). A meta-analysis reported that supplementation with pomegranate was unrelated to significant improvements in glycemic control, as assessed by fasting plasma glucose, HbA1c, insulin levels, or HOMA-IR [131]. However, trials in humans had small sample sizes, were conducted in heterogeneous populations (few including T2D individuals), and largely 
differed concerning the dose of pomegranate juice and the length of the intervention (often $<8$ weeks; $\geq 3$ months in two studies). The most used outcome was fasting plasma glucose, while HbA1c (a variable widely used in diabetes-related studies, which integrates glucose exposure in fasting and postprandial state) was often neglected. Importantly, there are no studies using hyperinsulinemic-euglycemic clamp (the gold-standard method to assess insulin sensitivity) or studies assessing incident diabetes from prediabetic subjects. Regarding inflammation and oxidative stress, dietary EA induced significant benefits in most in vitro, animal, and human studies. Evidence on the benefits of EA in non-enzymatic glycation in humans is incipient. Experimental research found that dietary EA prevented vascular complications. However, clinical research on the topic is still scarce, with microvascular complications and diabetic neuropathy actually unexplored.

Experimental research on the topic has two main caveats. First, several in vitro studies have been conducted in cell lines (immortalized), namely HepG2 hepatocytes, 3T3-L1 pre-adipocytes, and RAW 264.7 macrophages. Therefore, observed results in these studies may not completely translate to those reported in studies involving primary cell cultures. The second one concerns the studies testing EA in isolation. It is difficult to ascertain the translation of consumption of EA-rich foods to the EA-tested doses. In this regard, several factors should be considered, including (I) the amount of EA-related compound contained in a certain type of food (i.e., the content of ellagitannins in the edible part of pomegranates), which might vary in function of many agricultural factors; (II) the coexistence with other phytochemicals in a specific food that might influence the bioavailability of EA-related compound; (III) given the key role of gut in EA metabolism and absorption, the particular microbiota profile that each subject might translate into one-to-one differences in the hydrolysis of ellagitannins and further metabolism of EA to urolithins. This reinforces the need of well-designed and correctly powered randomized controlled trials on the topic.

Large randomized controlled trials involving dietary antioxidants in isolation have failed to achieve successful results for incident diabetes [132] and cardiovascular disease [133]. A plausible explanation for these neutral findings (in apparent conflict with many observational studies) is the fact that foods rich in antioxidants may have other bioactives which are not necessarily included in tested supplements. On the other hand, while adherence to a plant-based, antioxidant-rich dietary pattern (i.e., Mediterranean Diet) has been proven to be cardioprotective [134,135], it is difficult to disentangle the exact contribution of each dietary component on a hard-clinical endpoint. Randomized controlled trials testing a single food offer an approach between single components and dietary patterns $[136,137]$. Therefore, given that EA improves pancreatic $\beta$-cell functionality and postprandial hyperglycemia, subjects with prediabetes / metabolic syndrome would likely obtain the highest benefit of a short-term (4 week) or mid-term (6 months) dietary supplementation with an EA-rich food (i.e., pomegranate juice). The main outcomes would be changes in meal tolerance test (to evaluate the effect on postprandial glycemia) and in intravenous glucose tolerance test (IVGTT, to evaluate pancreatic $\beta$-cell functionality). Secondary outcomes would be hyperinsulinemic-euglycemic clamp (to assess changes in insulin sensitivity) and circulating markers of inflammation/oxidative stress.

Author Contributions: Conceptualization and design, A.J.A., A.S.-V., and I.L.; writing—original draft preparation, all authors; writing-review and editing, all authors. All authors have read and agreed to the published version of the manuscript.

Funding: A.S.-V. is recipient of the Instituto de Salud Carlos III Miguel Servet fellowship (grant CP II17/00029).

Acknowledgments: CIBEROBN and CIBERDEM are an initiative of ISCIII, Spain.

Conflicts of Interest: The authors declare no conflict of interest. 


\section{References}

1. Saeedi, P.; Petersohn, I.; Salpea, P.; Malanda, B.; Karuranga, S.; Unwin, N.; Colagiuri, S.; Guariguata, L.; Motala, A.A.; Ogurtsova, K.; et al. Global and regional diabetes prevalence estimates for 2019 and projections for 2030 and 2045, Results from the International Diabetes Federation Diabetes Atlas, 9th edition. Diabetes Res. Clin. Pract. 2019, 157. [CrossRef] [PubMed]

2. Chatterjee, S.; Khunti, K.; Davies, M.J. Type 2 diabetes. Lancet 2017, 389, 2239-2251. [CrossRef]

3. Buse, J.B.; Wexler, D.J.; Tsapas, A.; Rossing, P.; Mingrone, G.; Mathieu, C.; D'Alessio, D.A.; Davies, M.J. 2019 update to: Management of hyperglycaemia in type 2 diabetes, 2018. A consensus report by the American Diabetes Association (ADA) and the European Association for the Study of Diabetes (EASD). Diabetologia 2020, 63, 221-228. [CrossRef] [PubMed]

4. $\quad$ Evert, A.B.; Dennison, M.; Gardner, C.D.; Garvey, W.T.; Lau, K.H.; MacLeod, J.; Mitri, J.; Pereira, R.F.; Rawlings, K.; Robinson, S.; et al. Nutrition Therapy for Adults With Diabetes or Prediabetes: A Consensus Report. Diabetes Care 2019, 42, 731-754. [CrossRef]

5. Maritim, A.C.; Sanders, R.A.; Watkins, J.B. Diabetes, oxidative stress, and antioxidants: A review. J. Biochem. Mol. Toxicol. 2003, 17, 24-38. [CrossRef]

6. Giacco, F.; Brownlee, M. Oxidative stress and diabetic complications. Circ. Res. 2010, 107, $1058-1070$. [CrossRef]

7. Yuan, T.; Yang, T.; Chen, H.; Fu, D.; Hu, Y.; Wang, J.; Yuan, Q.; Yu, H.; Xu, W.; Xie, X. New insights into oxidative stress and inflammation during diabetes mellitus-accelerated atherosclerosis. Redox Biol. 2019, 20, 247-260. [CrossRef]

8. Del Bo, C.; Bernardi, S.; Marino, M.; Porrini, M.; Tucci, M.; Guglielmetti, S.; Cherubini, A.; Carrieri, B.; Kirkup, B.; Kroon, P.; et al. Systematic Review on Polyphenol Intake and Health Outcomes: Is there Sufficient Evidence to Define a Health-Promoting Polyphenol-Rich Dietary Pattern? Nutrients 2019, 11, 1355. [CrossRef]

9. Laddha, A.P.; Kulkarni, Y.A. Tannins and vascular complications of Diabetes: An update. Phytomedicine 2019, 56, 229-245. [CrossRef]

10. Sánchez-González, C.; Ciudad, C.J.; Noé, V.; Izquierdo-Pulido, M. Health benefits of walnut polyphenols: An exploration beyond their lipid profile. Crit. Rev. Food Sci. Nutr. 2017, 57, 3373-3383. [CrossRef]

11. García-Conesa, M.T.; Chambers, K.; Combet, E.; Pinto, P.; Garcia-Aloy, M.; Andrés-Lacueva, C.; PascualTeresa, D.; Mena, P.; Konic Ristic, A.; Hollands, W.J.; et al. Meta-Analysis of the Effects of Foods and Derived Products Containing Ellagitannins and Anthocyanins on Cardiometabolic Biomarkers: Analysis of Factors Influencing Variability of the Individual Responses. Int. J. Mol. Sci. 2018, 19, 694. [CrossRef] [PubMed]

12. Ríos, J.-L.; Giner, R.; Marín, M.; Recio, M. A Pharmacological Update of Ellagic Acid. Planta Med. 2018, 84, 1068-1093. [CrossRef] [PubMed]

13. Landete, J.M. Ellagitannins, ellagic acid and their derived metabolites: A review about source, metabolism, functions and health. Food Res. Int. 2011, 44, 1150-1160. [CrossRef]

14. García-Niño, W.R.; Zazueta, C. Ellagic acid: Pharmacological activities and molecular mechanisms involved in liver protection. Pharm. Res. 2015, 97, 84-103. [CrossRef]

15. Tomás-Barberán, F.A.; González-Sarrías, A.; García-Villalba, R.; Núñez-Sánchez, M.A.; Selma, M.V.; García-Conesa, M.T.; Espín, J.C. Urolithins, the rescue of "old" metabolites to understand a "new" concept: Metabotypes as a nexus among phenolic metabolism, microbiota dysbiosis, and host health status. Mol. Nutr. Food Res. 2017, 61, 1500901. [CrossRef]

16. Selma, M.V.; González-Sarrías, A.; Salas-Salvadó, J.; Andrés-Lacueva, C.; Alasalvar, C.; Örem, A.; Tomás-Barberán, F.A.; Espín, J.C. The gut microbiota metabolism of pomegranate or walnut ellagitannins yields two urolithin-metabotypes that correlate with cardiometabolic risk biomarkers: Comparison between normoweight, overweight-obesity and metabolic syndrome. Clin. Nutr. 2018, 37, 897-905. [CrossRef]

17. Romo-Vaquero, M.; Cortés-Martín, A.; Loria-Kohen, V.; Ramírez-de-Molina, A.; García-Mantrana, I.; Collado, M.C.; Espín, J.C.; Selma, M.V. Deciphering the Human Gut Microbiome of Urolithin Metabotypes: Association with Enterotypes and Potential Cardiometabolic Health Implications. Mol. Nutr. Food Res. 2019, 63, 1800958. [CrossRef]

18. Nakanishi, M.; Chen, Y.; Qendro, V.; Miyamoto, S.; Weinstock, E.; Weinstock, G.M.; Rosenberg, D.W. Effects of Walnut Consumption on Colon Carcinogenesis and Microbial Community Structure. Cancer Prev. Res. (Phila) 2016, 9, 692-703. [CrossRef] 
19. Zhao, W.; Shi, F.; Guo, Z.; Zhao, J.; Song, X.; Yang, H. Metabolite of ellagitannins, urolithin A induces autophagy and inhibits metastasis in human sw620 colorectal cancer cells. Mol. Carcinog. 2018, 57, 193-200. [CrossRef]

20. Stanisławska, I.J.; Piwowarski, J.P.; Granica, S.; Kiss, A.K. The effects of urolithins on the response of prostate cancer cells to non-steroidal antiandrogen bicalutamide. Phytomedicine 2018, 46, 176-183. [CrossRef]

21. Ding, X.; Jian, T.; Wu, Y.; Zuo, Y.; Li, J.; Lv, H.; Ma, L.; Ren, B.; Zhao, L.; Li, W.; et al. Ellagic acid ameliorates oxidative stress and insulin resistance in high glucose-treated HepG2 cells via miR-223/keap1-Nrf2 pathway. Biomed. Pharm. 2019, 110, 85-94. [CrossRef] [PubMed]

22. Fatima, N.; Hafizur, R.M.; Hameed, A.; Ahmed, S.; Nisar, M.; Kabir, N. Ellagic acid in Emblica officinalis exerts anti-diabetic activity through the action on $\beta$-cells of pancreas. Eur. J. Nutr. 2017, 56, 591-601. [CrossRef] [PubMed]

23. Rahimifard, M.; Moini-Nodeh, S.; Niaz, K.; Baeeri, M.; Jamalifar, H.; Abdollahi, M. Improvement of the functionality of pancreatic Langerhans islets via reduction of bacterial contamination and apoptosis using phenolic compounds. Iran. J. Basic Med. Sci. 2018, 21, 920-927. [CrossRef] [PubMed]

24. Les, F.; Arbonés-Mainar, J.M.; Valero, M.S.; López, V. Pomegranate polyphenols and urolithin A inhibit $\alpha$-glucosidase, dipeptidyl peptidase- 4 , lipase, triglyceride accumulation and adipogenesis related genes in 3T3-L1 adipocyte-like cells. J. Ethnopharmacol. 2018, 220, 67-74. [CrossRef]

25. Li, Y.; Wen, S.; Kota, B.P.; Peng, G.; Li, G.Q.; Yamahara, J.; Roufogalis, B.D. Punica granatum flower extract, a potent alpha-glucosidase inhibitor, improves postprandial hyperglycemia in Zucker diabetic fatty rats. J. Ethnopharmacol. 2005, 99, 239-244. [CrossRef]

26. Kam, A.; Li, K.M.; Razmovski-Naumovski, V.; Nammi, S.; Shi, J.; Chan, K.; Li, G.Q. A Comparative Study on the Inhibitory Effects of Different Parts and Chemical Constituents of Pomegranate on $\alpha$-Amylase and $\alpha$-Glucosidase. Phyther. Res. 2013, 27, 1614-1620. [CrossRef]

27. Wu, S.; Tian, L. A new flavone glucoside together with known ellagitannins and flavones with anti-diabetic and anti-obesity activities from the flowers of pomegranate (Punica granatum). Nat. Prod. Res. 2019, 33, 252-257. [CrossRef]

28. Bellesia, A.; Verzelloni, E.; Tagliazucchi, D. Pomegranate ellagitannins inhibit $\alpha$-glucosidase activity in vitro and reduce starch digestibility under simulated gastro-intestinal conditions. Int. J. Food Sci. Nutr. 2015, 66, 85-92. [CrossRef]

29. Yin, P.; Yang, L.; Xue, Q.; Yu, M.; Yao, F.; Sun, L.; Liu, Y. Identification and inhibitory activities of ellagic acid- and kaempferol-derivatives from Mongolian oak cups against $\alpha$-glucosidase, $\alpha$-amylase and protein glycation linked to type II diabetes and its complications and their influence on HepG2 cells' viability. Arab. J. Chem. 2018, 11, 1247-1259. [CrossRef]

30. Mohanty, I.R.; Borde, M.; Kumar, C.S.; Maheshwari, U. Dipeptidyl peptidase IV Inhibitory activity of Terminalia arjuna attributes to its cardioprotective effects in experimental diabetes: In silico, in vitro and in vivo analyses. Phytomedicine 2019, 57, 158-165. [CrossRef]

31. Makino-Wakagi, Y.; Yoshimura, Y.; Uzawa, Y.; Zaima, N.; Moriyama, T.; Kawamura, Y. Ellagic acid in pomegranate suppresses resistin secretion by a novel regulatory mechanism involving the degradation of intracellular resistin protein in adipocytes. Biochem. Biophys. Res. Commun. 2012, 417, 880-885. [CrossRef] [PubMed]

32. Toney, A.M.; Fan, R.; Xian, Y.; Chaidez, V.; Ramer-Tait, A.E.; Chung, S. Urolithin A, a Gut Metabolite, Improves Insulin Sensitivity Through Augmentation of Mitochondrial Function and Biogenesis. Obesity 2019, 27, 612-620. [CrossRef] [PubMed]

33. Parmar, H.S.; Kar, A. Medicinal Values of Fruit Peels from Citrus sinensis, Punica granatum, and Musa paradisiaca with Respect to Alterations in Tissue Lipid Peroxidation and Serum Concentration of Glucose, Insulin, and Thyroid Hormones. J. Med. Food 2008, 11, 376-381. [CrossRef] [PubMed]

34. Harzallah, A.; Hammami, M.; Kępczyńska, M.A.; Hislop, D.C.; Arch, J.R.; Cawthorne, M.A.; Zaibi, M.S. Comparison of potential preventive effects of pomegranate flower, peel and seed oil on insulin resistance and inflammation in high-fat and high-sucrose diet-induced obesity mice model. Arch. Physiol. Biochem. 2016, 122, 75-87. [CrossRef]

35. Neyrinck, A.M.; Van Hée, V.F.; Bindels, L.B.; De Backer, F.; Cani, P.D.; Delzenne, N.M. Polyphenol-rich extract of pomegranate peel alleviates tissue inflammation and hypercholesterolaemia in high-fat diet-induced obese mice: Potential implication of the gut microbiota. Br. J. Nutr. 2013, 109, 802-809. [CrossRef] 
36. Zilani, M.N.; Sultana, T.; Rahman, S.A.; Anisuzzman, M.; Islam, M.A.; Shilpi, J.A.; Hossain, M.G. Chemical composition and pharmacological activities of Pisum sativum. BMC Complement. Altern. Med. 2017, 17, 171. [CrossRef]

37. Fotschki, B.; Juśkiewicz, J.; Jurgoński, A.; Kosmala, M.; Milala, J.; Zduńczyk, Z.; Markowski, J. Grinding levels of raspberry pomace affect intestinal microbial activity, lipid and glucose metabolism in Wistar rats. Food Res. Int. 2019, 120, 399-406. [CrossRef]

38. Nankar, R.P.; Doble, M. Hybrid drug combination: Anti-diabetic treatment of type 2 diabetic Wistar rats with combination of ellagic acid and pioglitazone. Phytomedicine 2017, 37, 4-9. [CrossRef]

39. Farbood, Y.; Rashno, M.; Ghaderi, S.; Khoshnam, S.E.; Sarkaki, A.; Rashidi, K.; Rashno, M.; Badavi, M. Ellagic acid protects against diabetes-associated behavioral deficits in rats: Possible involved mechanisms. Life Sci. 2019, 225, 8-19. [CrossRef]

40. Das, A.K.; Mandal, S.C.; Banerjee, S.K.; Sinha, S.; Saha, B.P.; Pal, M. Studies on the hypoglycaemic activity of Punica granatum seed in streptozotocin induced diabetic rats. Phyther. Res. 2001, 15, 628-629. [CrossRef]

41. Manna, K.; Mishra, S.; Saha, M.; Mahapatra, S.; Saha, C.; Yenge, G.; Gaikwad, N.; Pal, R.; Oulkar, D.; Banerjee, K.; et al. Amelioration of diabetic nephropathy using pomegranate peel extract-stabilized gold nanoparticles: Assessment of NF-kB and Nrf2 signaling system. Int. J. Nanomed. 2019, 14, 1753-1777. [CrossRef] [PubMed]

42. Salwe, K.J.; Sachdev, D.O.; Bahurupi, Y.; Kumarappan, M. Evaluation of antidiabetic, hypolipedimic and antioxidant activity of hydroalcoholic extract of leaves and fruit peel of Punica granatum in male Wistar albino rats. J. Nat. Sci. Biol. Med. 2015, 6. [CrossRef] [PubMed]

43. Bagri, P.; Ali, M.; Aeri, V.; Bhowmik, M.; Sultana, S. Antidiabetic effect of Punica granatum flowers: Effect on hyperlipidemia, pancreatic cells lipid peroxidation and antioxidant enzymes in experimental diabetes. Food Chem. Toxicol. 2009, 47, 50-54. [CrossRef] [PubMed]

44. Wang, J.Y.; Zhu, C.; Qian, T.W.; Guo, H.; Wang, D.D.; Zhang, F.; Yin, X. Extracts of black bean peel and pomegranate peel ameliorate oxidative stress-induced hyperglycemia in mice. Exp. Ther. Med. 2015, 9, $43-48$. [CrossRef]

45. Yeh, Y.-T.; Chiang, A.-N.; Hsieh, S.-C. Chinese Olive (Canarium album L.) Fruit Extract Attenuates Metabolic Dysfunction in Diabetic Rats. Nutrients 2017, 9, 1123. [CrossRef]

46. Taheri Rouhi, S.Z.; Sarker, M.M.R.; Rahmat, A.; Alkahtani, S.A.; Othman, F. The effect of pomegranate fresh juice versus pomegranate seed powder on metabolic indices, lipid profile, inflammatory biomarkers, and the histopathology of pancreatic islets of Langerhans in streptozotocin-nicotinamide induced type 2 diabetic Sprague-Dawley rats. BMC Complement. Altern. Med. 2017, 17, 156. [CrossRef]

47. Aboonabi, A.; Rahmat, A.; Othman, F. Antioxidant effect of pomegranate against streptozotocin-nicotinamide generated oxidative stress induced diabetic rats. Toxicol. Rep. 2014, 1, 915-922. [CrossRef]

48. El-Beih, N.M.; Ramadan, G.; El-Husseiny, E.A.; Hussein, A.M. Effects of pomegranate aril juice and its punicalagin on some key regulators of insulin resistance and oxidative liver injury in streptozotocinnicotinamide type 2 diabetic rats. Mol. Biol. Rep. 2019, 46, 3701-3711. [CrossRef]

49. Parmar, H.S.; Kar, A. Antidiabetic potential of Citrus sinensis and Punica granatum peel extracts in alloxan treated male mice. Biofactors 2007, 31, 17-24. [CrossRef]

50. Middha, S.K.; Usha, T.; Pande, V. Pomegranate peel attenuates hyperglycemic effects of alloxan-induced diabetic rats. Excli J. 2014, 13, 223-224.

51. El-Hadary, A.E.; Ramadan, M.F. Phenolic profiles, antihyperglycemic, antihyperlipidemic, and antioxidant properties of pomegranate (Punica granatum) peel extract. J. Food Biochem. 2019, 43, e12803. [CrossRef] [PubMed]

52. Das, S.; Barman, S. Antidiabetic and antihyperlipidemic effects of ethanolic extract of leaves of Punica granatum in alloxan-induced non-insulin-dependent diabetes mellitus albino rats. Indian J. Pharm. 2012, 44, 219-224. [CrossRef]

53. Gharib, E.; Montasser Kouhsari, S. Study of the Antidiabetic Activity of Punica granatum L. Fruits Aqueous Extract on the Alloxan-Diabetic Wistar Rats. Iran J. Pharm. Res. IJPR 2019, 18, 358-368. [PubMed]

54. Raafat, K.; Samy, W. Amelioration of diabetes and painful diabetic neuropathy by Punica granatum L. Extract and its spray dried biopolymeric dispersions. Evid. -Based Complement. Altern. Med. 2014, 2014. [CrossRef]

55. Abu-Gharbieh, E.; Shehab, N.G. Therapeutic potentials of Crataegus azarolus var. eu-azarolus Maire leaves and its isolated compounds. BMC Complement. Altern. Med. 2017, 17, 218. [CrossRef] [PubMed] 
56. Yin, P.; Wang, Y.; Yang, L.; Sui, J.; Liu, Y. Hypoglycemic Effects in Alloxan-Induced Diabetic Rats of the Phenolic Extract from Mongolian Oak Cups Enriched in Ellagic Acid, Kaempferol and Their Derivatives. Molecules 2018, 23, 1046. [CrossRef] [PubMed]

57. Jelodar, G.; Mohsen, M.; Shahram, S. Effect of walnut leaf, coriander and pomegranate on blood glucose and histopathology of pancreas of alloxan induced diabetic rats. Afr. J. Tradit. Complement. Altern. Med. Ajtcam. 2007, 4, 299-305. [CrossRef]

58. Amin, M.M.; Arbid, M.S. Estimation of ellagic acid and/or repaglinide effects on insulin signaling, oxidative stress, and inflammatory mediators of liver, pancreas, adipose tissue, and brain in insulin resistant/type 2 diabetic rats. Appl. Physiol. Nutr. Metab. 2017, 42, 181-192. [CrossRef]

59. Yoshimura, Y.; Nishii, S.; Zaima, N.; Moriyama, T.; Kawamura, Y. Ellagic acid improves hepatic steatosis and serum lipid composition through reduction of serum resistin levels and transcriptional activation of hepatic ppara in obese, diabetic KK-A(y) mice. Biochem. Biophys. Res. Commun. 2013, 434, 486-491. [CrossRef]

60. Polce, S.A.; Burke, C.; França, L.M.; Kramer, B.; de Andrade Paes, A.M.; Carrillo-Sepulveda, M.A. Ellagic Acid Alleviates Hepatic Oxidative Stress and Insulin Resistance in Diabetic Female Rats. Nutrients 2018, 10, 531. [CrossRef]

61. Banihani, S.A.; Makahleh, S.M.; El-Akawi, Z.; Al-Fashtaki, R.A.; Khabour, O.F.; Gharibeh, M.Y.; Saadah, N.A.; Al-Hashimi, F.H.; Al-Khasieb, N.J. Fresh pomegranate juice ameliorates insulin resistance, enhances $\beta$-cell function, and decreases fasting serum glucose in type 2 diabetic patients. Nutr. Res. 2014, 34, 862-867. [CrossRef] [PubMed]

62. Kerimi, A.; Nyambe-Silavwe, H.; Gauer, J.S.; Tomás-Barberán, F.A.; Williamson, G. Pomegranate juice, but not an extract, confers a lower glycemic response on a high-glycemic index food: Randomized, crossover, controlled trials in healthy subjects. Am. J. Clin. Nutr. 2017, 106, 1384-1393. [CrossRef] [PubMed]

63. Kelishadi, R.; Gidding, S.S.; Hashemi, M.; Hashemipour, M.; Zakerameli, A.; Poursafa, P. Acute and long term effects of grape and pomegranate juice consumption on endothelial dysfunction in pediatric metabolic syndrome. J. Res. Med. Sci. 2011, 16, 245-253. [PubMed]

64. Parsaeyan, N.; Mozaffari-Khosravi, H.; Mozayan, M.R. Effect of pomegranate juice on paraoxonase enzyme activity in patients with type 2 diabetes. J. Diabetes Metab. Disord. 2012,11, 11. [CrossRef]

65. Shishehbor, F.; Mohammad Shahi, M.; Zarei, M.; Saki, A.; Zakerkish, M.; Shirani, F. Effects of Concentrated Pomegranate Juice on Subclinical Inflammation and Cardiometabolic Risk Factors for Type 2 Diabetes: A Quasi-Experimental Study. Int. J. Endocrinol. Metab. 2016, 14, e33835. [CrossRef]

66. Sumner, M.D.; Elliott-Eller, M.; Weidner, G.; Daubenmier, J.J.; Chew, M.H.; Marlin, R.; Raisin, C.J.; Ornish, D. Effects of Pomegranate Juice Consumption on Myocardial Perfusion in Patients With Coronary Heart Disease. Am. J. Cardiol. 2005, 96, 810-814. [CrossRef]

67. Cerdá, B.; Soto, C.; Albaladejo, M.D.; Martinez, P.; Sanchez-Gascon, F.; Tomás-Barberán, F.; Espin, J.C. Pomegranate juice supplementation in chronic obstructive pulmonary disease: A 5-week randomized, double-blind, placebo-controlled trial. Eur. J. Clin. Nutr. 2006, 60, 245-253. [CrossRef]

68. González-Ortiz, M.; Martínez-Abundis, E.; Espinel-Bermúdez, M.C.; Pérez-Rubio, K.G. Effect of pomegranate juice on insulin secretion and sensitivity in patients with obesity. Ann. Nutr. Metab. 2011, 58, 220-223. [CrossRef]

69. Tsang, C.; Smail, N.F.; Almoosawi, S.; Davidson, I.; Al-Dujaili, E.A.S. Intake of polyphenol-rich pomegranate pure juice influences urinary glucocorticoids, blood pressure and homeostasis model assessment of insulin resistance in human volunteers. J. Nutr. Sci. 2012, 1, e9. [CrossRef]

70. Sohrab, G.; Nasrollahzadeh, J.; Zand, H.; Amiri, Z.; Tohidi, M.; Kimiagar, M. Effects of pomegranate juice consumption on inflammatory markers in patients with type 2 diabetes: A randomized, placebo-controlled trial. J. Res. Med. Sci. 2014, 19, 215-220.

71. Asgary, S.; Sahebkar, A.; Afshani, M.R.; Keshvari, M.; Haghjooyjavanmard, S.; Rafieian-Kopaei, M. Clinical Evaluation of Blood Pressure Lowering, Endothelial Function Improving, Hypolipidemic and Anti-Inflammatory Effects of Pomegranate Juice in Hypertensive Subjects. Phyther. Res. 2014, 28, 193-199. [CrossRef] [PubMed]

72. Park, J.E.; Kim, J.Y.; Kim, J.; Kim, Y.J.; Kim, M.J.; Kwon, S.W.; Kwon, O. Pomegranate vinegar beverage reduces visceral fat accumulation in association with AMPK activation in overweight women: A double-blind, randomized, and placebo-controlled trial. J. Funct. Foods 2014, 8, 274-281. [CrossRef] 
73. Fuster-Muñoz, E.; Roche, E.; Funes, L.; Martínez-Peinado, P.; Sempere, J.M.; Vicente-Salar, N. Effects of pomegranate juice in circulating parameters, cytokines, and oxidative stress markers in endurance-based athletes: A randomized controlled trial. Nutrition 2016, 32, 539-545. [CrossRef] [PubMed]

74. Manthou, E.; Georgakouli, K.; Deli, C.K.; Sotiropoulos, A.; Fatouros, I.G.; Kouretas, D.; Haroutounian, S.; Matthaiou, C.; Koutedakis, Y.; Jamurtas, A.Z. Effect of pomegranate juice consumption on biochemical parameters and complete blood count. Exp. Ther. Med. 2017, 14, 1756-1762. [CrossRef] [PubMed]

75. Sohrab, G.; Ebrahimof, S.; Sotoudeh, G.; Neyestani, T.R.; Angoorani, P.; Hedayati, M.; Siasi, F. Effects of pomegranate juice consumption on oxidative stress in patients with type 2 diabetes: A single-blind, randomized clinical trial. Int. J. Food Sci. Nutr. 2017, 68, 249-255. [CrossRef] [PubMed]

76. Moazzen, H.; Alizadeh, M. Effects of Pomegranate Juice on Cardiovascular Risk Factors in Patients with Metabolic Syndrome: A Double-Blinded, Randomized Crossover Controlled Trial. Plant Foods Hum. Nutr. 2017, 72, 126-133. [CrossRef] [PubMed]

77. Heber, D.; Seeram, N.P.; Wyatt, H.; Henning, S.M.; Zhang, Y.; Ogden, L.G.; Dreher, M.; Hill, J.O. Safety and Antioxidant Activity of a Pomegranate Ellagitannin-Enriched Polyphenol Dietary Supplement in Overweight Individuals with Increased Waist Size. J. Agric. Food Chem. 2007, 55, 10050-10054. [CrossRef]

78. Hosseini, B.; Saedisomeolia, A.; Wood, L.G.; Yaseri, M.; Tavasoli, S. Effects of pomegranate extract supplementation on inflammation in overweight and obese individuals: A randomized controlled clinical trial. Complement Clin. Pr. 2016, 22, 44-50. [CrossRef]

79. Pérez-Ramírez, I.F.; de Diego, E.H.; Riomoros-Arranz, M.; Reynoso-Camacho, R.; Saura-Calixto, F.; Pérez-Jiménez, J. Effects of acute intake of grape/pomegranate pomace dietary supplement on glucose metabolism and oxidative stress in adults with abdominal obesity. Int. J. Food Sci. Nutr. 2019, 1-12. [CrossRef]

80. Tsalamandris, S.; Antonopoulos, A.S.; Oikonomou, E.; Papamikroulis, G.A.; Vogiatzi, G.; Papaioannou, S.; Deftereos, S.; Tousoulis, D. The role of inflammation in diabetes: Current concepts and future perspectives. Eur. Cardiol. Rev. 2019, 14, 50-59. [CrossRef]

81. Oguntibeju, O.O. Type 2 diabetes mellitus, oxidative stress and inflammation: Examining the links. Int. J. Physiol. Pathophysiol. Pharmacol. 2019, 11, 45-63. [PubMed]

82. Rozentsvit, A.; Vinokur, K.; Samuel, S.; Li, Y.; Gerdes, A.M.; Carrillo-Sepulveda, M.A. Ellagic Acid Reduces High Glucose-Induced Vascular Oxidative Stress Through ERK1/2/NOX4 Signaling Pathway. Cell Physiol. Biochem. 2017, 44, 1174-1187. [CrossRef] [PubMed]

83. Xu, J.; Zhao, Y.; Aisa, H.A. Anti-inflammatory effect of pomegranate flower in lipopolysaccharide (LPS)-stimulated RAW264.7 macrophages. Pharm. Biol. 2017, 55, 2095-2101. [CrossRef] [PubMed]

84. Basu, A.; Newman, E.D.; Bryant, A.L.; Lyons, T.J.; Betts, N.M. Pomegranate Polyphenols Lower Lipid Peroxidation in Adults with Type 2 Diabetes but Have No Effects in Healthy Volunteers: A Pilot Study. J. Nutr. Metab. 2013, 2013, 1-7. [CrossRef] [PubMed]

85. Sohrab, G.; Nasrollahzadeh, J.; Tohidi, M.; Zand, H.; Nikpayam, O. Pomegranate Juice Increases Sirtuin1 Protein in Peripheral Blood Mononuclear Cell from Patients with Type 2 Diabetes: A Randomized Placebo Controlled Clinical Trial. Metab. Syndr. Relat. Disord. 2018, 16, 446-451. [CrossRef] [PubMed]

86. Karasu, Ç.; Cumaoğlu, A.; Gúrpinar, A.; Kartal, M.; Kovacikova, L.; Milackova, I.; Stefek, M. Aldose reductase inhibitory activity and antioxidant capacity of pomegranate extracts. Interdiscip. Toxicol. 2012, 5, 15-20. [CrossRef]

87. Rozenberg, O.; Howell, A.; Aviram, M. Pomegranate juice sugar fraction reduces macrophage oxidative state, whereas white grape juice sugar fraction increases it. Atherosclerosis 2006, 188, 68-76. [CrossRef]

88. Gharib, E.; Montasser Kouhsari, S.; Izad MPunica granatum, L. Fruit Aqueous Extract Suppresses Reactive Oxygen Species-Mediated p53/p65/miR-145 Expressions followed by Elevated Levels of irs-1 in Alloxan-Diabetic Rats. Cell J. 2018, 19, 520-527. [CrossRef]

89. Rock, W.; Rosenblat, M.; Miller-Lotan, R.; Levy, A.P.; Elias, M.; Aviram, M. Consumption of Wonderful Variety Pomegranate Juice and Extract by Diabetic Patients Increases Paraoxonase 1 Association with High-Density Lipoprotein and Stimulates Its Catalytic Activities. J. Agric. Food Chem. 2008, 56, 8704-8713. [CrossRef]

90. Sohrab, G.; Angoorani, P.; Tohidi, M.; Tabibi, H.; Kimiagar, M.; Nasrollahzadeh, J. Pomegranate (Punicagranatum) juice decreases lipid peroxidation, but has no effect on plasma advanced glycated end-products in adults with type 2 diabetes: A randomized double-blind clinical trial. Food Nutr. Res. 2015, 59, 28551. [CrossRef] 
91. Rosenblat, M.; Hayek, T.; Aviram, M. Anti-oxidative effects of pomegranate juice (PJ) consumption by diabetic patients on serum and on macrophages. Atherosclerosis 2006, 187, 363-371. [CrossRef] [PubMed]

92. Díaz-Rubio, M.E.; Pérez-Jiménez, J.; Martínez-Bartolomé, M.Á.; Álvarez, I.; Saura-Calixto, F. Regular consumption of an antioxidant-rich juice improves oxidative status and causes metabolome changes in healthy adults. Plant Foods Hum. Nutr. 2015, 70, 9-14. [CrossRef] [PubMed]

93. Nowotny, K.; Jung, T.; Höhn, A.; Weber, D.; Grune, T. Advanced glycation end products and oxidative stress in type 2 diabetes mellitus. Biomolecules 2015, 5, 194-222. [CrossRef] [PubMed]

94. Liu, W.; Ma, H.; Frost, L.; Yuan, T.; Dain, J.A.; Seeram, N.P. Pomegranate phenolics inhibit formation of advanced glycation endproducts by scavenging reactive carbonyl species. Food Funct. 2014, 5, 2996-3004. [CrossRef] [PubMed]

95. Kumagai, Y.; Nakatani, S.; Onodera, H.; Nagatomo, A.; Nishida, N.; Matsuura, Y.; Kobata, K.; Wada, M. Anti-Glycation Effects of Pomegranate (Punica granatum L.) Fruit Extract and Its Components in Vivo and in Vitro. J. Agric. Food Chem. 2015, 63, 7760-7764. [CrossRef] [PubMed]

96. Dorsey, P.G.; Greenspan, P. Inhibition of nonenzymatic protein glycation by pomegranate and other fruit juices. J. Med. Food 2014, 17, 447-454. [CrossRef] [PubMed]

97. Raghu, G.; Jakhotia, S.; Yadagiri Reddy, P.; Kumar, P.A.; Bhanuprakash Reddy, G. Ellagic acid inhibits non-enzymatic glycation and prevents proteinuria in diabetic rats. Food Funct. 2016, 7, 1574-1583. [CrossRef]

98. Alicic, R.Z.; Rooney, M.T.; Tuttle, K.R. Diabetic kidney disease: Challenges, progress, and possibilities. Clin. J. Am. Soc. Nephrol. 2017, 12, 2032-2045. [CrossRef]

99. Neuen, B.L.; Young, T.; Heerspink, H.J.; Neal, B.; Perkovic, V.; Billot, L.; Mahaffey, K.W.; Charytan, D.M.; Wheeler, D.C.; Arnott, C.; et al. SGLT2 inhibitors for the prevention of kidney failure in patients with type 2 diabetes: A systematic review and meta-analysis. Lancet Diabetes Endocrinol. 2019, 7, 845-854. [CrossRef]

100. Bolignano, D.; Cernaro, V.; Gembillo, G.; Baggetta, R.; Buemi, M.; D’Arrigo, G. Antioxidant agents for delaying diabetic kidney disease progression: A systematic review and meta-analysis. PLoS ONE 2017, 12, e0178699. [CrossRef]

101. Chao, C.; Mong, M.; Chan, K.; Yin, M. Anti-glycative and anti-inflammatory effects of caffeic acid and ellagic acid in kidney of diabetic mice. Mol. Nutr. Food Res. 2010, 54, 388-395. [CrossRef] [PubMed]

102. Mohan, M.; Waghulde, H.; Kasture, S. Effect of pomegranate juice on Angiotensin II-induced hypertension in diabetic wistar rats. Phyther. Res. 2010, 24, S196-S203. [CrossRef] [PubMed]

103. Ankita, P.; Deepti, B.; Nilam, M. Flavonoid rich fraction of Punica granatum improves early diabetic nephropathy by ameliorating proteinuria and disturbed glucose homeostasis in experimental animals. Pharm. Biol. 2015, 53, 61-71. [CrossRef] [PubMed]

104. Zhou, B.; Li, Q.; Wang, J.; Chen, P.; Jiang, S. Ellagic acid attenuates streptozocin induced diabetic nephropathy via the regulation of oxidative stress and inflammatory signaling. Food Chem. Toxicol. 2019, 123, $16-27$. [CrossRef] [PubMed]

105. Ahad, A.; Ganai, A.A.; Mujeeb, M.; Siddiqui, W.A. Ellagic acid, an NF-кB inhibitor, ameliorates renal function in experimental diabetic nephropathy. Chem. Biol. Interact. 2014, 219, 64-75. [CrossRef] [PubMed]

106. Solomon, S.D.; Chew, E.; Duh, E.J.; Sobrin, L.; Sun, J.K.; VanderBeek, B.L.; Wykoff, C.C.; Gardner, T.W. Diabetic retinopathy: A position statement by the American Diabetes Association. Diabetes Care 2017, 40, 412-418. [CrossRef]

107. Díaz-López, A.; Babio, N.; Martínez-González, M.A.; Corella, D.; Amor, A.J.; Fitó, M.; Estruch, R.; Arós, F.; Gómez-Gracia, E.; Fiol, M.; et al. Mediterranean diet, retinopathy, nephropathy, and microvascular diabetes Complications: A post Hoc analysis of a randomized trial. Diabetes Care 2015, 38, 2134-2141. [CrossRef]

108. Sala-Vila, A.; Díaz-López, A.; Valls-Pedret, C.; Cofán, M.; García-Layana, A.; Lamuela-Raventós, R.-M.; Castañer, O.; Zanon-Moreno, V.; Martinez-Gonzalez, M.A.; Toledo, E.; et al. Dietary marine $\omega-3$ fatty acids and incident sight-threatening retinopathy in middle-aged and older individuals with type 2 diabetes: Prospective investigation from the PREDIMED trial. JAMA Ophthalmol. 2016, 134, 1142-1149. [CrossRef]

109. Raghu, G.; Akileshwari, C.; Reddy, V.S.; Reddy, G.B. Attenuation of diabetic retinopathy in rats by ellagic acid through inhibition of AGE formation. J. Food Sci. Technol. 2017, 54, 2411-2421. [CrossRef]

110. Tugcu, B.; Nacaroglu, S.A.; Gedikbasi, A.; Uhri, M.; Acar, N.; Ozdemir, H. Protective effect of pomegranate juice on retinal oxidative stress in streptozotocin-induced diabetic rats. Int. J. Ophthalmol. 2017, 10, 1662-1668. [CrossRef] 
111. Rawshani, A.; Rawshani, A.; Franzén, S.; Sattar, N.; Eliasson, B.; Svensson, A.M.; Zethelius, B.; Miftaraj, M.; McGuire, D.K.; Rosengren, A.; et al. Risk factors, mortality, and cardiovascular outcomes in patients with type 2 diabetes. N. Engl. J. Med. 2018, 379, 633-644. [CrossRef] [PubMed]

112. Catalan, M.; Herreras, Z.; Pinyol, M.; Sala-Vila, A.; Amor, A.J.; de Groot, E.; Gilabert, R.; Ros, E.; Ortega, E. Prevalence by sex of preclinical carotid atherosclerosis in newly diagnosed type 2 diabetes. Nutr. Metab. Cardiovasc. Dis. Nmcd. 2015, 25, 742-748. [CrossRef] [PubMed]

113. Amor, A.J.; Catalan, M.; Pérez, A.; Herreras, Z.; Pinyol, M.; Sala-Vila, A.; Cofán, M.; Gilabert, R.; Ros, E.; Ortega, E. Nuclear magnetic resonance lipoprotein abnormalities in newly-diagnosed type 2 diabetes and their association with preclinical carotid atherosclerosis. Atherosclerosis 2016, 247. [CrossRef] [PubMed]

114. McHugh, K.; DeVore, A.D.; Wu, J.; Matsouaka, R.A.; Fonarow, G.C.; Heidenreich, P.A.; Yancy, C.W.; Green, J.B.; Altman, N.; Hernandez, A.F. Heart Failure With Preserved Ejection Fraction and Diabetes: JACC State-of-the-Art Review. J. Am. Coll. Cardiol. 2019, 73, 602-611. [CrossRef]

115. Sattar, N.; Rawshani, A.; Franzén, S.; Rawshani, A.; Svensson, A.M.; Rosengren, A.; McGuire, D.K.; Eliasson, B.; Gudbjörnsdottir, S. Age at Diagnosis of Type 2 Diabetes Mellitus and Associations With Cardiovascular and Mortality Risks: Findings From the Swedish National Diabetes Registry. Circulation 2019, 139, 2228-2237. [CrossRef]

116. Gæde, P.; Pedersen, O. Intensive integrated therapy of type 2 diabetes: Implications for long-term prognosis. Diabetes 2004, 53. [CrossRef]

117. Kozakova, M.; Morizzo, C.; Goncalves, I.; Natali, A.; Nilsson, J.; Palombo, C. Cardiovascular organ damage in type 2 diabetes mellitus: The role of lipids and inflammation. Cardiovasc. Diabetol. 2019, 18, 61. [CrossRef]

118. Aviram, M.; Volkova, N.; Coleman, R.; Dreher, M.; Reddy, M.K.; Ferreira, D.; Rosenblat, M. Pomegranate Phenolics from the Peels, Arils, and Flowers Are Antiatherogenic: Studies in Vivo in Atherosclerotic Apolipoprotein E-Deficient (E 0 ) Mice and in Vitro in Cultured Macrophages and Lipoproteins. J. Agric. Food Chem. 2008, 56, 1148-1157. [CrossRef]

119. De Nigris, F.; Balestrieri, M.L.; Williams-Ignarro, S.; D’Armiento, F.P.; Fiorito, C.; Ignarro, L.J.; Napoli, C. The influence of pomegranate fruit extract in comparison to regular pomegranate juice and seed oil on nitric oxide and arterial function in obese Zucker rats. Nitric Oxide 2007, 17, 50-54. [CrossRef]

120. Panchal, S.K.; Ward, L.; Brown, L. Ellagic acid attenuates high-carbohydrate, high-fat diet-induced metabolic syndrome in rats. Eur. J. Nutr. 2013, 52, 559-568. [CrossRef]

121. Kesavan, R.; Ganugula, R.; Avaneesh, T.; Kumar, U.; Reddy, G.B.; Dixit, M. Ellagic acid inhibits PDGF-BBinduced vascular smooth muscle cell proliferation and prevents atheroma formation in streptozotocin-induced diabetic rats. J. Nutr. Biochem. 2013, 24, 1830-1839. [CrossRef]

122. Chao, P.; Hsu, C.; Yin, M. Anti-inflammatory and anti-coagulatory activities of caffeic acid and ellagic acid in cardiac tissue of diabetic mice. Nutr. Metab. 2009, 6, 33. [CrossRef] [PubMed]

123. Huang, T.H.; Peng, G.; Kota, B.P.; Li, G.Q.; Yamahara, J.; Roufogalis, B.D.; Li, Y. Pomegranate flower improves cardiac lipid metabolism in a diabetic rat model: Role of lowering circulating lipids. Br. J. Pharm. 2005, 145, 767-774. [CrossRef] [PubMed]

124. Huang, T.H.; Yang, Q.; Harada, M.; Li, G.Q.; Yamahara, J.; Roufogalis, B.D.; Li, Y. Pomegranate flower extract diminishes cardiac fibrosis in Zucker diabetic fatty rats: Modulation of cardiac endothelin-1 and nuclear factor-kappaB pathways. J. Cardiovasc. Pharm. 2005, 46, 856-862. [CrossRef]

125. Savi, M.; Bocchi, L.; Mena, P.; Dall'Asta, M.; Crozier, A.; Brighenti, F.; Stilli, D.; Del Rio, D. In vivo administration of urolithin A and B prevents the occurrence of cardiac dysfunction in streptozotocin-induced diabetic rats. Cardiovasc. Diabetol. 2017, 16, 80. [CrossRef]

126. Namekata, I.; Hamaguchi, S.; Wakasugi, Y.; Ohhara, M.; Hirota, Y.; Tanaka, H. Ellagic acid and gingerol, activators of the sarco-endoplasmic reticulum Ca2+-ATPase, ameliorate diabetes mellitus-induced diastolic dysfunction in isolated murine ventricular myocardia. Eur. J. Pharm. 2013, 706, 48-55. [CrossRef]

127. Mauricio, D.; Alonso, N.; Gratacòs, M. Chronic Diabetes Complications: The Need to Move beyond Classical Concepts. Trends Endocrinol. Metab. 2020. [CrossRef]

128. Vadini, F.; Simeone, P.G.; Boccatonda, A.; Guagnano, M.T.; Liani, R.; Tripaldi, R.; Di Castelnuovo, A.; Cipollone, F.; Consoli, A.; Santilli, F. Liraglutide improves memory in obese patients with prediabetes or early type 2 diabetes: A randomized, controlled study. Int. J. Obes. 2020. [CrossRef] 
129. Uzar, E.; Alp, H.; Cevik, M.U.; Frrat, U.; Evliyaoglu, O.; Tufek, A.; Altun, Y. Ellagic acid attenuates oxidative stress on brain and sciatic nerve and improves histopathology of brain in streptozotocin-induced diabetic rats. Rats. Neurol. Sci 2012, 33, 567-574. [CrossRef]

130. Cambay, Z.; Baydas, G.; Tuzcu, M.; Bal, R. Pomegranate (Punica granatum L.) flower improves learning and memory performances impaired by diabetes mellitus in rats. Acta Physiol. Hung. 2011, 98, 409-420. [CrossRef]

131. Huang, H.; Liao, D.; Chen, G.; Chen, H.; Zhu, Y. Lack of efficacy of pomegranate supplementation for glucose management, insulin levels and sensitivity: Evidence from a systematic review and meta-analysis. Nutr. J. 2017, 16, 67. [CrossRef] [PubMed]

132. Kataja-Tuomola, M.; Sundell, J.R.; Männistö, S.; Virtanen, M.J.; Kontto, J.; Albanes, D.; Virtamo, J. Effect of alpha-tocopherol and beta-carotene supplementation on the incidence of type 2 diabetes. Diabetologia 2008, 51, 47-53. [CrossRef] [PubMed]

133. Jenkins, D.J.A.; Spence, J.D.; Giovannucci, E.L.; Kim, Y.I.; Josse, R.; Vieth, R.; Blanco Mejia, S.; Viguiliouk, E.; Nishi, S.; Sahye-Pudaruth, S.; et al. Supplemental Vitamins and Minerals for CVD Prevention and Treatment. J. Am. Coll. Cardiol. 2018, 71, 2570-2584. [CrossRef] [PubMed]

134. De Lorgeril, M.; Salen, P.; Martin, J.L.; Monjaud, I.; Delaye, J.; Mamelle, N. Mediterranean diet, traditional risk factors, and the rate of cardiovascular complications after myocardial infarction: Final report of the Lyon Diet Heart Study. Circulation 1999, 99, 779-785. [CrossRef]

135. Estruch, R.; Ros, E.; Salas-Salvadó, J.; Covas, M.I.; Corella, D.; Arós, F.; Gómez-Gracia, E.; Ruiz-Gutiérrez, V.; Fiol, M.; Lapetra, J.; et al. Primary Prevention of Cardiovascular Disease with a Mediterranean Diet Supplemented with Extra-Virgin Olive Oil or Nuts. N. Engl. J. Med. 2018, 378, e34. [CrossRef]

136. Balfegó, M.; Canivell, S.; Hanzu, F.A.; Sala-Vila, A.; Martínez-Medina, M.; Murillo, S.; Mur, T.; Ruano, E.G.; Linares, F.; Porras, N.; et al. Effects of sardine-enriched diet on metabolic control, inflammation and gut microbiota in drug-naïve patients with type 2 diabetes: A pilot randomized trial. Lipids Health Dis. 2016, 15, 78. [CrossRef]

137. Sala-Vila, A.; Valls-Pedret, C.; Rajaram, S.; Coll-Padrós, N.; Cofán, M.; Serra-Mir, M.; Pérez-Heras, A.M.; Roth, I.; Freitas-Simoes, T.M.; Doménech, M.; et al. Effect of a 2-year diet intervention with walnuts on cognitive decline. The Walnuts and Healthy Aging (WAHA) study: A randomized controlled trial. Am. J. Clin. Nutr. 2020, 111, 590-600. [CrossRef]

Publisher's Note: MDPI stays neutral with regard to jurisdictional claims in published maps and institutional affiliations.

(C) 2020 by the authors. Licensee MDPI, Basel, Switzerland. This article is an open access article distributed under the terms and conditions of the Creative Commons Attribution (CC BY) license (http://creativecommons.org/licenses/by/4.0/). 